\title{
What does comanagement offer? Exploring users' knowledge through mental models in the fishery of La Encrucijada Biosphere Reserve, Mexico
}

\author{
Laia d'Armengol $^{1}, \underline{\text { Isabel Ruiz-Mallén }}^{2}$, Cecile Barnaud $^{3}$ and Esteve Corbera $^{1,4,5}$
}

\begin{abstract}
In the context of collaborative resource management, mental models can provide insights on participants' understanding of the resource management system and in so doing allow researchers and practitioners to derive lessons about the success or failure of comanagement approaches. We analyzed individual and group mental models in the comanaged small-scale fishery of La Encrucijada, Mexico, active since 2009. Mental models reveal a strong consensus around the idea that the comanagement initiative is a governmentled partnership to subsidize fishers. This belief reflects a history of state paternalism and coexists with a diversity of views about who are the actors involved in comanagement, their role in the fishery, and the resources mobilized through comanagement. We argue that local participants' limited understanding of the collaborative mechanisms established by the comanagement initiative suggests a failure of the promoting actors to communicate the initiative's environmental and social goals and to exploit its transformative potential in terms of actors' empowerment and participation in the long term. This research contributes to the burgeoning literature on the use of mental models as a means to unravel the cognitive aspects that may lie underneath the success or failure of natural resource governance.
\end{abstract}

Key Words: collaborative management; protected area; shared decision making; small-scale fishery

\section{INTRODUCTION}

Collaborative resource management, the sharing of decisionmaking power between at least resource users and government (Berkes 2009), has proven successful in managing natural resource systems through, for example, enhancing the fit between regulatory norms and local conditions (Gutiérrez et al. 2011, d'Armengol et al. 2018). Comanagement can improve the ecological conditions of fisheries and the livelihoods of users through strengthening compliance with management rules and facilitating social learning among participants (Evans et al. 2011). These participants (e.g., public authorities, private business, scientific experts, groups of users, social interest groups, and nongovernmental organizations) collaborate by sharing problem perspectives and working with different kinds of knowledge and competencies (Bouwen and Taillieu 2004). When collaboration is combined with adaptive management processes in which norms are continuously revised and changed, comanagement becomes better suited to deal with uncertainty and complexity (Holling 1978, Sandström and Rova 2010).

Collaboration through social learning processes involves different parties framing and reframing the definitions of the issues at stake (Bouwen and Taillieu 2004, Armitage et al. 2008). There should however be certain agreement on some issues, usually referred to as shared understanding (Olsson et al. 2004, Sandström and Rova 2010). A shared understanding is a structure of collectively created meaning that emerges in and helps coordinating activities of a group to achieve shared goals (Ansell and Gash 2008, Berkes 2010, Mathevet et al. 2011). This requires acknowledging different understandings and identities and including a diversity of inputs (Bouwen and Taillieu 2004). Achieving a shared understanding or common view is thus often mentioned as a facilitator of successful comanagement (Olsson et al. 2004, Sandström and Rova 2010).
Ideally, the stakeholders involved in comanagement should share an understanding of the problem to be solved, the goals of collaboration, and the management strategy (Carlsson 2000, Ansell and Gash 2008, Berkes 2010, Sandström and Rova 2010, Sandström 2011). It is argued that the lack of common views on these issues can lead to the failure of comanagement processes because they can deter effective and inclusive collaboration (Baird et al. 2016). However, other authors suggest that the achievement of a shared understanding can be illusory in the context of, for example, protected areas in which competing interests and expectations among conservationists and locals may be the norm (Oldekop et al. 2016). In this regard, a competing approach calls for embracing the diversity of understandings and working with dissent (Peterson et al. 2006, Matulis and Moyer 2017). We want to gain insights into this debate by exploring to what degree the participants involved in fishery comanagement have a shared understanding of this system.

Stakeholders' individual and shared understandings can be analyzed through individual mental models (Jones et al. 2011, Mathevet et al. 2011). Mental models are internal cognitive representations of an external reality that people construct and use to interact with this reality (Lynam and Brown 2012, Jones et al. 2014). They show the understanding of how a given socialecological system works according to different people (Lynam and Brown 2012). They are by nature subjective and therefore incomplete representations, the result of personal experiences, perceptions, and understandings of the world, that people use to filter new information, reason and make decisions, and adapt to changing circumstances through learning (Jones et al. 2011). Mental models can be elicited through individual interviews or collective workshops aimed at building individual or collective representations of social-ecological systems (Mathevet et al. 2011). 
Fig. 1. Location of La Encrucijada Biosphere Reserve and the cooperatives participating in comanagement. Sources: GADM the Database of Global Administrative Areas (https://gadm. org/), Gobierno del Estado de Chiapas: Geoweb Chiapas 3.0 (http://map.ceieg.chiapas.gob.mx/ geoweb/), Comisión Nacional de Áreas Naturales Protegidas.

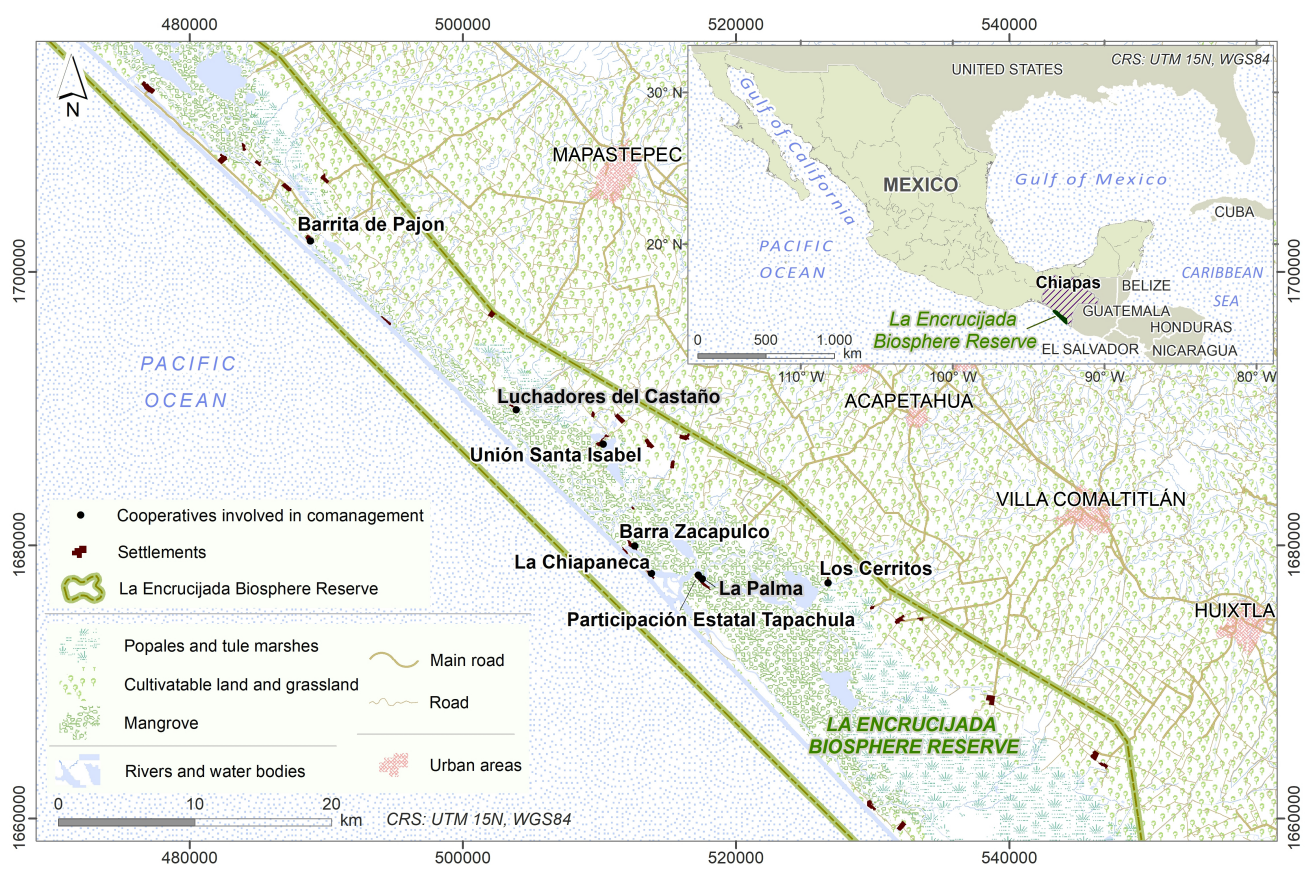

In natural resource management literature, recent research has used individual or collective elicitation of mental models to explore to what extent participants share understandings of four key comanagement aspects: (1) the social-ecological system in focus (Vuillot et al. 2016, Salliou and Barnaud 2017); (2) the management problem, such as perceptions of the causes of fish decline (Stone-Jovicich et al. 2011, Horowitz et al. 2018); (3) goals and visions, such as priorities for water use (Stone-Jovicich et al. 2011); and (4) management strategies (Pahl-Wostl and Hare 2004, Mathevet et al. 2011, Galafassi et al. 2017). We use mental models to represent and explore understandings of a comanaged smallscale fishery located in La Encrucijada Biosphere Reserve, Mexico. We assess the degree of shared understanding of the comanagement system among the participants and discuss why a shared understanding of comanagement as a subsidy-driven resource management strategy was enough to prompt collaboration, despite a lack of consensus on which collaboration mechanisms were made available to participants and what these should be for.

\section{METHODS}

\section{The fishery of La Encrucijada}

The protected area of La Encrucijada (Fig. 1) was established in 1996 and extends over 144,868 ha along the Mexican Pacific coast, in the state of Chiapas, Mexico. It is a UNESCO Biosphere Reserve, as well as a Ramsar wetland of international importance. The reserve's estuarine system is home to the most productive and well-developed mangroves of the American Pacific coast (Instituto Nacional de Ecología 1999), sheltering a high biological diversity (Contreras 2010) and encompassing the highest fish richness of all the estuarine-lagoon systems along the Mexican Pacific (Gómez González et al. 2012). As for many other protected areas around the world, the establishment of the reserve resulted in conflicts between locals and the national government because the reserve's management plan imposed restrictions on resource access and use and was regarded as illegitimate by local communities (Romero-Berny and Guichard-Romero 2015).

Eighty-two communities encompassing approximately 27,000 people are located within the reserve (Instituto Nacional de Ecología 1999). Their main economic activities are agriculture, livestock breeding, and fishing. The latter is the main livelihood source for those living in the core areas of the reserve, who fish for subsistence and commercial purposes. Educational levels among fishers are low and, on average, they have about four years of school attendance (Rodríguez Perafán 2014). From a total of 24 fishing cooperatives, 18 have territorial use rights through concessions in the estuarine system and 6 have fishing permits to fish in open waters. Those using the estuarine system can fish up to 46 different species of fish, including crustaceans and bivalves (Rodríguez Perafán 2014), often on fibre-made cayucos with outboard motors, and employing a variety of fishing gear, including cast nets, trammel nets, hooks, harpoons, stow nets, and the collective shrimp corral. The other 6 cooperatives use boats and trammel nets to fish in open waters and harvest more than 21 species of fishes and crustaceans (CONAPESCA 2015).

In 2009, the local office of the National Commission of Natural Protected Areas (CONANP) in La Encrucijada started a 
comanagement system. The initiative was regarded by fishers and CONANP as an opportunity to collaborate on minimizing the decline of fish stocks observed and to improve the livelihoods of fishing families, while adhering to the conservation objectives of the reserve. The initiative also attracted NGOs to the area and enhanced the collaboration with research institutions, which until then had only focused on studying the ecological aspects of $\mathrm{La}$ Encrucijada while overlooking fishers' interests. The eight fishing cooperatives involved gathered most fishers around one of the main lagoon systems, Chantuto-Panzacola. Six of the cooperatives, including those that were involved in our study and known as La Palma and Luchadores del Castaño (hereafter El Castaño), fished in the estuaries, and two others operated in open waters. The comanagement system also involved government agencies with fisheries responsibilities at different administrative levels: (1) at the local level, municipality councils (Acapetahua and Mapastepec); (2) at the regional level, the Chiapas' government Fishery and Aquaculture Department (SEPESCA); and (3) at the national level, the National Commission of Aquaculture and Fishing (CONAPESCA). Two research centres contributed with their knowledge about the fishery: El Colegio de la Frontera (ECOSUR) and the Universidad de las Artes y las Ciencias de Chiapas (UNICACH). Finally, the NGOs Centro de Agroecología San Francisco de Asís (CASFA), first, and Acción Cultural Madre Tierra (ACMT), later, were contracted by CONANP to facilitate comanagement meetings. A third NGO, Ser Integral Chiapas, supported activities to promote the commercialization of local fishery products in regional and national markets.

Although CONAPESCA was (and still is) the legal authority when it comes to regulating fisheries' management in Mexico, participants in the comanagement initiative of La Encrucijada regularly use formal and informal mechanisms to make joint resource-management decisions at the fishery and cooperatives levels. At the fishery level, they all meet twice per year in the technical-scientific committee to discuss the performance of comanagement and advise the leaders of the fishing cooperatives. In turn, such leaders meet every month in the intercooperative committee with CONANP to define a shared commercialization strategy and to negotiate and establish common fishing norms (insofar as these would not contradict national legislation). For example, they agreed on not fishing juveniles and establishing voluntary local no-take areas. At the cooperative level, members of each cooperative meet regularly to implement the agreements reached in the technical-scientific committee, for instance, to determine the exact location of no-take areas. Finally, CONANP organizes training activities for fishers, in which researchers or representatives of governmental agencies are often invited to talk.

\section{Data collection}

Fieldwork was conducted by the first author from April to September 2015 and comprised participant observation and semistructured and diagrammatical interviews to elicit individual mental models. Participant observation was performed during one of the monthly meetings of the intercooperative committee and the only meeting of the technical-scientific committee that took place during fieldwork. The first author also attended the fishers' biannual assembly in La Palma and one of the fishers' weekly meetings in El Castaño. During these meetings, she listened and took notes, and only talked if requested for explaining the purposes of her research and answering related questions. She also engaged in one monitoring trip and two fishing trips that were documented in field notebooks.

Semistructured interviews were conducted in an initial phase of fieldwork to investigate the history and the outcomes of the comanagement system and to identify the two most relevant fishing cooperatives for further investigation. The first author interviewed 12 key informants who were directly involved in the comanagement system, including members of government agencies, fishing cooperatives, the NGOs ACMT and CASFA, and the research centre ECOSUR. After this process, the cooperatives of La Palma and El Castaño were chosen because they were the two most active at the time of fieldwork and had been involved in the initiative since the beginning.

Next, we elicited individual mental models, i.e., graphs in which the nodes are concepts or objects and the links connecting nodes are relationships or associations between these concepts or objects (Dray et al. 2006). Following Horowitz and colleagues (2018), we differentiated the stakeholders at the fishery level into four main types: fishing cooperatives, government agencies, NGOs, and academic institutions. The first author interviewed one representative of each of these organizations, who were actively participating in the committees of the comanagement system (Table 1). Interviewees were those staff members having more regular contact with the comanagement initiative or holding a post of responsibility. We could only interview one researcher who had studied the social organization of fishers in the region and had engaged with comanagement activities during the first two years. A few other academics could not be interviewed because they were not available at the time fieldwork was conducted.

We asked interviewees to provide responses as the organization (not as individuals) to capture the organization's understanding of comanagement. We acknowledge, however, that this reduced sampling could entail limitations because we could miss nuances in such understanding. At the cooperative level, we also elicited the mental models of the members (local fishers) of La Palma and El Castaño. In total, 31 diagrammatic interviews were conducted with members of 14 organizations (Table 1). Interviews were held at the individual's workplace or at the correspondent cooperative's office, and only in one case was the interview held in a public café. Finally, the first author also interviewed fishers: 8 members of La Palma and 11 members of El Castaño who were selected with convenience sampling as they approached the cooperative facilities.

Prior to starting each interview, the first author explained that the purpose of the exercise was to draw a diagram of the actors, resources, and activities related to the "responsible fishing program," which was the way all participants referred to the comanagement system. She explained to each interviewee that the term "actors" referred to any organization, individual, or group of people related to the program, while the term "resources" referred to natural or other material goods that were important for the program. In the case of fishers, she emphasized that such resources could include those goods extracted from nature, the community, or from outside that the program needed to be effective. These two terms were drawn from the actors, resources, dynamics and interactions (ARDI) method that has been commonly employed in the elicitation of individual mental 
models (IMMs; Etienne et al. 2008, Mathevet et al. 2011, Vuillot et al. 2016). The first author did not ask interviewees about dynamics or drivers of change as in the ARDI method but instead asked for activities involving actors and resources in the program. This modification was aimed at adapting the methodology to the representation of the local management system and to facilitate comprehension by less literate interviewees. Toward the end of the interview, she asked interviewees to describe with a verb all connections between two concepts (actors, resources, or activities).

Table 1. Sampling strategy for the mental models' interviews. Note: CONANP = National Commission of Natural Protected Areas; CONAPESCA = National Commission of Aquaculture and Fishing; SEPESCA = Chiapas' Government Fishery and Aquaculture Department; ACMT = Acción Cultural Madre Tierra; CASFA = Centro de Agroecología San Francisco de Asís; ECOSUR = El Colegio de la Frontera; UNICACH = Universidad de las Artes y las Ciencias de Chiapas.

\begin{tabular}{|c|c|c|}
\hline \multicolumn{3}{|c|}{ By type of comanagement stakeholder } \\
\hline $\begin{array}{l}\text { Type of } \\
\text { stakeholder }\end{array}$ & $\begin{array}{l}\text { Organizations involved in } \\
\text { the comanagement } \\
\text { initiative }\end{array}$ & Interviewees \\
\hline $\begin{array}{l}\text { Fishing } \\
\text { cooperatives }\end{array}$ & $\begin{array}{l}\text { Barra Zacapulco, Barrita } \\
\text { de Pajón, La Chiapaneca, } \\
\text { La Palma, Los Cerritos, } \\
\text { Luchadores del Castaño, } \\
\text { Participación Estatal } \\
\text { Tapachula, Unión Santa } \\
\text { Isabel }\end{array}$ & $\begin{array}{l}6 \text { interviewees: the leader of } \\
\text { each cooperative at the time } \\
\text { of fieldwork (except Barra } \\
\text { Zacapulco and La } \\
\text { Chiapaneca) }\end{array}$ \\
\hline $\begin{array}{l}\text { Government } \\
\text { agencies }\end{array}$ & $\begin{array}{l}\text { Acapetahua city council, } \\
\text { CONANP, } \\
\text { CONAPESCA, } \\
\text { Mapastepec city council, } \\
\text { SEPESCA }\end{array}$ & $\begin{array}{l}4 \text { interviewees: a staff } \\
\text { member of each agency } \\
\text { (except Mapastepec city } \\
\text { council) }\end{array}$ \\
\hline NGOs & $\begin{array}{l}\text { ACMT, CASFA, Ser } \\
\text { Integral Chiapas }\end{array}$ & $\begin{array}{l}3 \text { interviewees: one staff } \\
\text { member from each } \\
\text { organization }\end{array}$ \\
\hline $\begin{array}{l}\text { Research } \\
\text { centres }\end{array}$ & ECOSUR, UNICACH & 1 researcher from ECOSUR \\
\hline \multicolumn{3}{|c|}{ By fishing cooperative } \\
\hline $\begin{array}{l}\text { Fishing } \\
\text { cooperative }\end{array}$ & $\begin{array}{l}\text { Members } \\
\text { (i.e., fishers) }\end{array}$ & Interviewees \\
\hline La Palma & 126 & 8 \\
\hline El Castaño & 36 & 11 \\
\hline
\end{tabular}

To start illustrating the mental model and overcome any initial discomfort toward drawing, the first author asked each interviewee to explain, in their own words, what the responsible fishing program was. As the interviewee talked, the interviewer identified the actors, resources, and activities from their words and wrote them down on post-its, displayed them on a whiteboard made of two DIN A4 laminated cardboards, united them through arrows, and labeled each arrow with a verb that described the relation between every pair of concepts united. Next, she asked the interviewee if the resulting diagram corresponded to what they meant and modified accordingly as needed. When the interviewee agreed with the representation, the interviewer encouraged them to continue drawing the mental model themselves. However, if the interviewee did not feel confident, she assisted in the drawing until all actors, resources, activities, and interactions among them were represented. This assistance of the interviewer enabled capturing the mental models of less literate interviewees (some fishers) who otherwise would have been omitted from the sample. When this happened, and to avoid any subjective interpretation, the interviewer wrote down the concepts exactly as the interviewee named them. Also, when the diagram was done, she asked the interviewee if what she wrote matched their meaning. As many cardboards as necessary were added to fit the growing diagram.

All fieldwork interviews were conducted after receiving prior informed consent, and they were carried out in Spanish. Most of them were recorded after being granted permission by the interviewee, and typically lasted between 30 minutes and 1 hour and a half. In the case of diagrammatic ones, each diagram was coded and photographed for subsequent analysis. Appendix 1 shows images of the elicitation process and an original representation of a mental model.

\section{Data analysis}

We analyzed IMMs and consensual group mental models (GMMs), which are aggregations of several IMMs representing only the most shared features, through a qualitative approach (Vuillot et al. 2016) by comparing how actors, resources, activities, and interactions were displayed in each mental model. The analysis of GMMs was aimed at revealing insights about the shared understanding within and across stakeholder types whereas the analysis of IMMs was intended to counteract the simplification of information in GMMs and reveal interesting differences within stakeholder types.

We built three GMMs of cooperative leaders, representatives of government agencies, and representatives of NGOs. We grouped these stakeholder types because it is usually assumed that each type shares similar versions of reality based on shared values and norms (Horowitz et al. 2018). We did not build a GMM of the research centers because, as noted earlier, we could only interview one researcher. We also built two GMMs from the IMMs of the members of two fishing cooperatives, La Palma and El Castaño.

To facilitate the analysis of the IMMs and the construction of the GMMs, we homogenized all concepts with similar meanings appearing in different IMMs (Vuillot et al. 2016). For instance, "fishers", "cooperative members," and "cooperative" were always transcribed as "fishers," because all fishers involved in comanagement are cooperative members and, locally, when people talked about the cooperative they referred to the cooperative members. Similarly, "fish," "fish species," and "fishery resources" were always transcribed as "fish stock." We are aware that such homogenization of concepts may imply a certain degree of subjectivity but establishing a predefined set of concepts to choose from would have been more biased. Also, when applicable, groups of concepts and relations (subgraphs) were condensed and replaced by a single concept that captured the meaning of the subgraph (Özesmi and Özesmi 2003). For instance, "generating added value," "better harvest registration," "better facilities," and "better prices" were grouped under the term "commercialization," and "wood," "wild fauna," and "birds" under the term "natural resources" (see Appendix 2 for the list of homogenized and aggregated concepts). When a concept was not clear, we checked the recorded interview to clarify its meaning. Appendix 3 shows all the IMMs elicited. 
We then created five adjacency matrices (Özesmi and Özesmi 2003, Vuillot et al. 2016) to capture the information of the IMMs of cooperative leaders, government, and NGOs representatives and the fishers of La Palma and El Castaño. All concepts of the IMMs headed the rows and columns of the matrix, and each link uniting two concepts was identified in the corresponding cell with the code/s of the IMMs that mentioned the link. Those interactions connecting the two same concepts that were mentioned by at least $30 \%$ of the IMMs were represented in the GMMs (Vuillot et al. 2016). This percentage was increased to $50 \%$ in the NGOs' GMM to represent interactions mentioned in at least two of the three IMMs from NGO members analyzed. This consensus criterion was used to simplify the group model using a percentage of interactions that allowed the showing of the important interactions without getting overwhelmed by concepts and interactions (Fairweather 2010).

\section{RESULTS}

We compare the GMMs of interviewed stakeholder types at the fishery level, i.e., the leaders of the fishing cooperatives (Fig. 2), the representatives of the government agencies (Fig. 3), and the representatives of NGOs (Fig. 4), as well as the IMM of the researcher (Fig. 5). We also compare the GMMs of the cooperative members of La Palma and El Castaño at the cooperatives' level (Fig. 6). The comparison of mental models revolves around four key components emerging from the analysis: actors, transfer of resources, the role of fishers, and collaborative decision making.

Fig. 2. Group mental model of the leaders of fishing cooperatives.

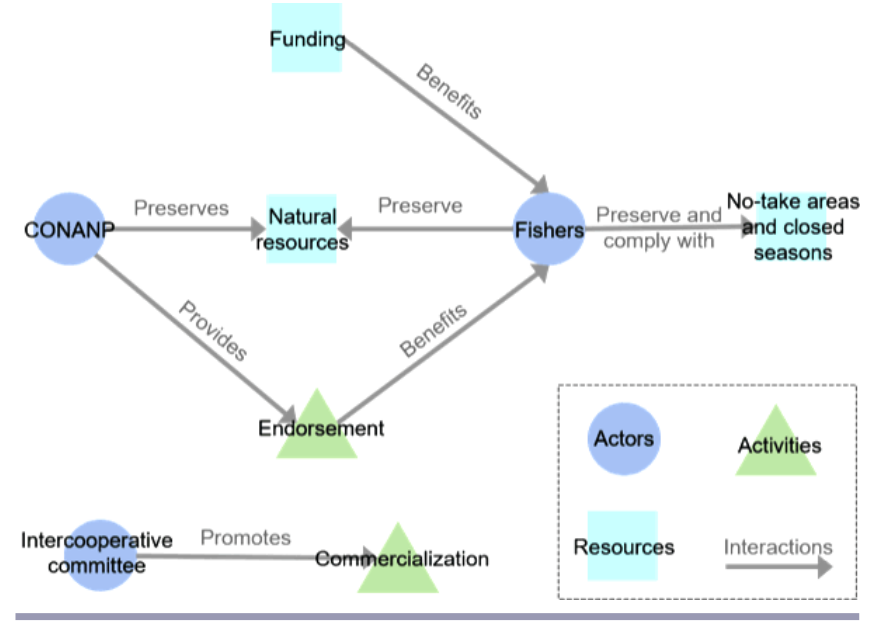

\section{Actors}

All GMMs identify fishers and government as key actors of the comanagement initiative. However, the models differ in the kind of government agencies represented. The leaders of fishing cooperatives and the fishers of La Palma and El Castaño only identify CONANP, which has always been the agency promoting comanagement activities and thus in regular contact with fishers. The GMM of the NGO representatives also represents SEPESCA, the fisheries department of the regional government. The mental model of the researcher also includes CONAPESCA, the fisheries department of the national government, and the GMM of the government representatives also identify city councils. Rather surprisingly, one cooperative leader and three fishers do not represent government agencies in their IMMs (Coop4, LaPa6, LuCa02, and LuCa06; Appendix 3), reflecting a community-based management approach.

Fig. 3. Group mental model of the representatives of the government agencies.

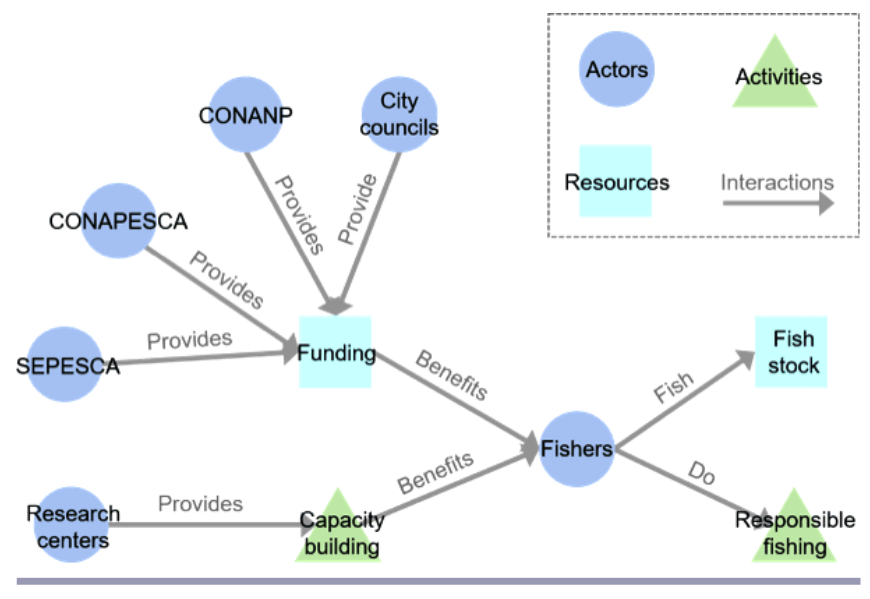

Fig. 4. Group mental model of the representatives of nongovernmental organizations (NGOs).

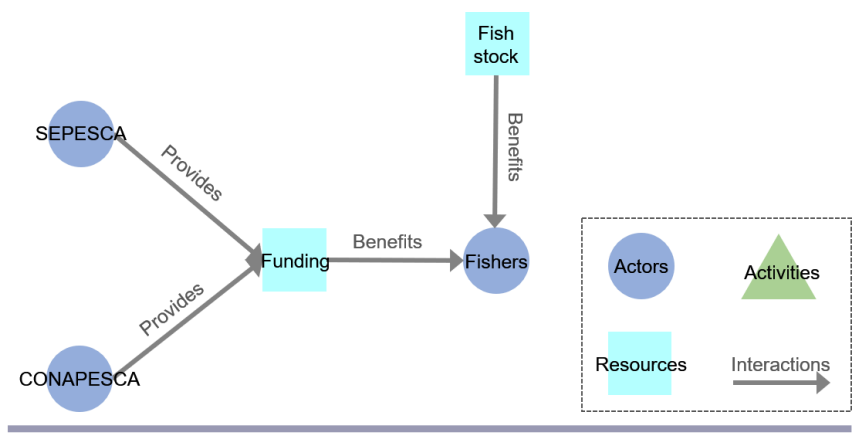

Both government representatives and the researcher identify research centers as a third actor in the comanagement system, whereas the fishers' leaders represent the intercooperative committee. Other actors appearing in several IMMs (Appendix 3) are NGOs, illegal fishers, community children, fishers' families, and donors. Finally, some actors of the comanagement system only appear in one IMM each (Appendix 3), including the technical-scientific committee, the federation of cooperatives, cooperative leaders, companies, and intermediaries (LaPa5).

\section{Transfer of resources}

All GMMs represent the transfer of resources as the central tenet of the comanagement initiative. These resources are mostly economic and flow from government to fishers. The GMM of government representatives also shows the mobilization of knowledge through capacity building from research centers to fishers. In contrast, the GMM of El Castaño reflects that fishers consider that these activities are implemented by CONANP and 
not by academics. The GMM of fishers' leaders and the IMM of the researcher share the idea that CONANP transfers resources to fishers as a means to incentivize and guide the latter in the pursuit of comanagement goals.

Fig. 5. Individual mental model of the representative of a research center.

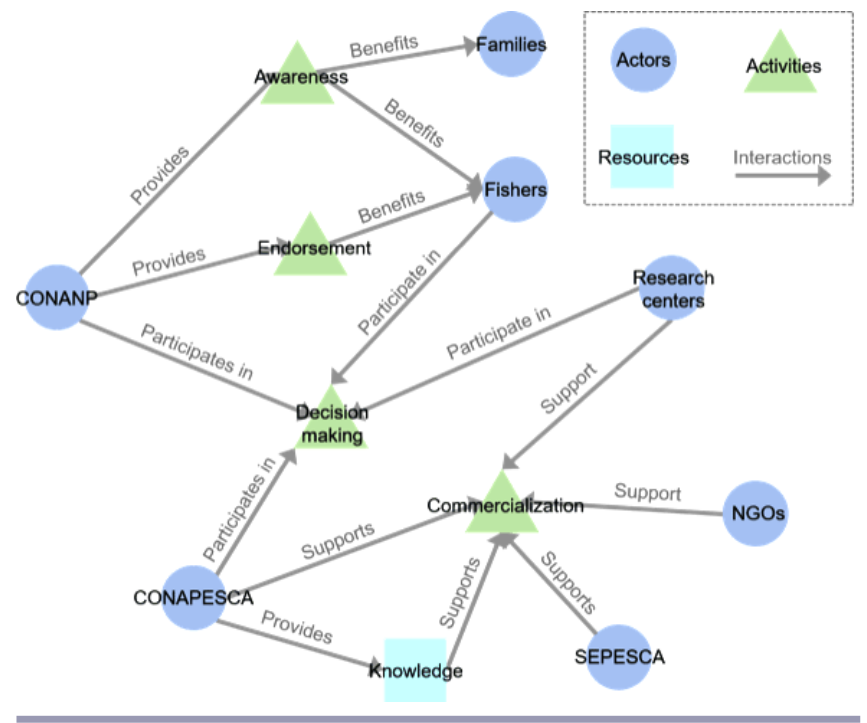

Fig. 6. Group mental model of members of two fishing cooperatives: (a) La Palma and (b) El Castaño.

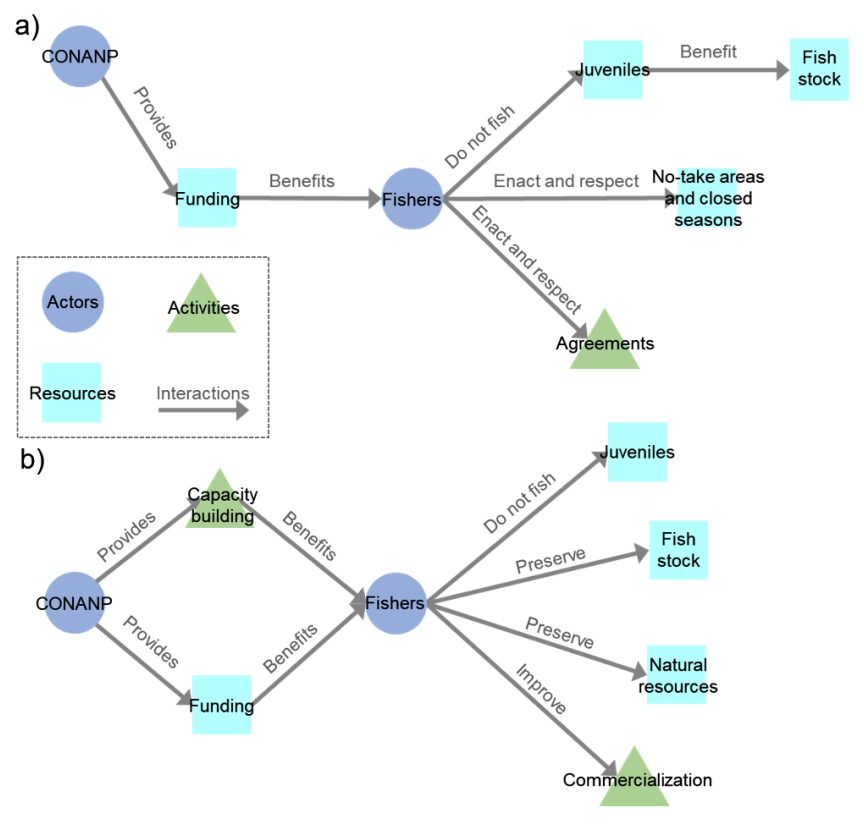

The IMMs (Appendix 3) represent other resources mobilized within comanagement. A cooperative leader notes that fishers receive infrastructure from government agencies (Coop1). Three other IMMs highlight that capacity building activities, which benefit fishers, are conducted by government agencies and research centres, as well as by NGOs ( $\mathrm{LaPa} 2, \mathrm{LuCa} 01$, and Gov1) and donors ( $\mathrm{LaPa} 2)$. Other IMMs include capacity building activities that benefit other actors besides fishers, such as children (LuCa07 and LuCa08,) and families (Gov1). Finally, the IMM of an NGO staff member considers that CONANP benefits fishers as well as NGOs (NGO1).

\section{Fishers' role}

Although all GMMs seem to agree on the fact that government is supporting fishers through funding, they differ greatly in representing what fishers do. The GMM of the cooperatives' leaders represents fishers as those actors who conserve natural resources and comply with local no-take areas and closed seasons. The GMM of La Palma represents fishers as those who reach agreements and establish and enforce no-take areas and closed seasons, including the act of not fishing juveniles. Similarly, the GMM of El Castaño represents fishers as actors who do not fish juveniles and who conserve fish and other natural resources. This GMM also represents fishers as actors who aim to improve the commercialization of fish harvests. Interestingly, the IMM of the researcher is the only mental model that represents fishers as key participants in collaborative decision making, alongside CONAPESCA, CONANP, and research centers.

By contrast, the GMM and IMMs of government representatives consider fishers as those responsible for fishing activities and its sustainability, which is a more general understanding than those highlighted above. Surprisingly, the IMMs of the three NGOs' representatives (Appendix 3) show very different representations of what fishers do in the comanagement context, which are not reflected in the GMM of the NGOs' representatives. Although one mental model does not show any action from fishers (NGO1), another one represents fishers communicating with CONANP (NGO2), and the last one represents a number of activities fishers do, from updating knowledge to changing public policies and promoting actor alliances (NGO3).

Other IMMs (Appendix 3) also show other activities performed by fishers within the comanagement system. For example, the IMM of a cooperative leader represents fishers as key surveillance actors. The IMMs of some members from La Palma and El Castaño represent fishers as people who use legal gears for fishing and who educate children about resource management. Finally, the IMMs of some government representatives also illustrate fishers reaching management agreements and promoting new forms of fish commercialization.

\section{Collaborative decision making}

Only the GMMs of La Palma fishers and of the cooperatives' leaders represent decision-making processes. In the former model, fishers reach internal agreements and declare no-take areas and closed seasons, and there is not any other actor involved in decision making. In addition to fishers, the second model also identifies the intercooperative committee as a key actor in decision making, although no other actor is made explicit in this regard. In the case of IMMs (Appendix 3), only a few fishers and government representatives represent shared decision-making components between government and fishers (LaPa1, LaPa2, LaPa7, LuCa03, LuCa05, and Gov1). The mental model of the researcher also does it and adds a third actor, research centers. 


\section{DISCUSSION}

Our results suggest that participants in c-management share an understanding of the system as a framework that facilitates the economic support of government toward fishers instead of one that promotes collaborative decision making. Participants have a diversity of views on the actors involved, the other resources transferred, the role of fishers, and who (if any) participates in decision making. These results nuance previous studies showing that shared understandings favor collaboration (e.g., Berkes 2010, Mathevet et al. 2011), and suggest that agreement on a key aspect of the comanagement system is enough to start collaborating, and that contrasting views on who participates in decision making do not jeopardize comanagement, at least in the short term. A diversity of understandings might coexist in a context of collaborative decision making, as suggested by authors such as Leach and Fairhead (2001) who claimed that collaboration does not necessarily need to be based on consensus, and that it is important instead to recognize the plurality of stakeholders' perspectives and interests.

Sandström and Rova (2010) suggested that participants in comanagement approaches need to share at least a common perception of the state of the resource system and a common goal to trigger collaboration. In La Encrucijada, a shared understanding based on the support provided by the government to fishers, together with a perception of declining fish populations and the desire to conserve fish stocks and improve the fishers' livelihoods, was sufficient to trigger the start of the comanagement initiative. However, a shared understanding of the collaborative mechanisms underlying comanagement might be necessary to sustain comanagement in the long term. Also, a shared understanding of the social rules underlying the comanagement system might help to increase the social legitimacy of the system.

Our findings align with the well-established pattern of paternalistic resource provision in Mexico (and elsewhere) in which the State has sought to involve cooperatives and other rural groups in development and conservation projects through the provision of subsidies and infrastructure, particularly since the 1920s (Young 2001, García Lozano et al. 2019). In our case study, and despite the opening of the rural sector to private investment and the reduction of agrarian subsidies from the 1980s onward (García Lozano et al. 2019), cooperative members have continued to receive support from CONAPESCA in the form of fuel and fishing equipment subsidies, and from SEPESCA through direct payments to support fishers' income. This can explain why fishers continue to regard government-led projects mostly as sources of additional revenue and not as projects that entail collaborative decision making. Mental models are indeed subjective and incomplete representations of reality, which are based on longterm knowledge structures, assumptions, and normative ideas (Jones et al. 2011); based in our case on assumptions of how relationships between fishers and government work. The actors may hold ingrained representations of a past reality that resists change. They filter new information from experience and communication in a way that reinforces rather than challenges their previous mental models (Abel et al. 1998, Daw 2008), because it is cognitively easier than acquiring new assumptions for fundamentally new systems (Galafassi et al. 2018).
Armitage and colleagues (2018) suggested that comanagement requires that participants move beyond single-loop learning, i.e., changing behaviors, and second loop-learning, i.e., changing values and norms, to achieve triple-loop learning, i.e., challenging the governance system that frames the way people learn (Armitage et al. 2008). For instance, in an Inuit's narwhal comanagement experience, the dominant management worldview or model changed from the distinct management paradigms of hunters and government to a collaborative community-based management approach (Diduck et al. 2005). Similarly, in the Vietnamese Mekong Delta, collaboration between local governments and farmers resulted in a shared understanding of the local water management system that included collaborative mechanisms for decision making (Tran et al. 2019). Unlike these cases, our analysis of La Encrucijada shows an absence of triple-loop learning. The fishers involved in c-management have been able to fix routine errors, such as reducing the fishing of juveniles, evidencing singleloop learning. Similarly, fishers' leaders and the representatives of the other organizations involved in comanagement have agreed on the goals of the comanagement process, which reflects secondloop learning (Diduck et al. 2005). The IMMs reflect that some individuals understand the new joint decision-making mechanisms in comanagement, but this individual learning has not been encoded in social memory (Diduck et al. 2005). Therefore, social triple-loop learning in La Encrucijada has not yet occurred.

The literature suggests that mental models evolve slowly and mainly through experience and communication with other actors (Lundholm and Stöhr 2014). The absence of triple-loop learning might mean that six years of comanagement have not been enough to guarantee sufficient time and social interactions to trigger these profound cognitive changes (Suškevičs et al. 2019). It might also mean that further commitment to shared decision making by all actors is required (Armitage et al. 2018). Government actors, in particular, should dedicate more time and resources to consultation and participatory processes with all actors involved to increase the knowledge about comanagement means and ends and to readapt management rules so that these better fit with changing ecological conditions and local aspirations. In doing so, the transformative potential of comanagement in terms of social empowerment may surface.

\section{CONCLUSION}

Our findings suggest that stakeholders in La Encrucijada have a shared understanding of the new management system as a government-led partnership to support fishers economically, which mostly reflects the previous institutional design, based on governmental protectionism and lack of collaborative decision making. This shared understanding has allowed the emergence of comanagement despite a diversity of understandings on the actors involved, the kind of resources transferred, and the role of fishers in comanagement. However, more time, resources, social interactions, and collaboration are necessary to trigger more profound social-learning processes that challenge the actual representations of the management system and include collaborative decision making in participants' views of comanagement. The findings suggest that a shared understanding among stakeholders of the new collaborative mechanisms in place is not a prerequisite for comanagement but might be necessary to sustain a socially legitimate collaboration in the long term. 
Responses to this article can be read online at: https://www.ecologyandsociety.org/issues/responses. $\mathrm{php} / 12177$

\section{Acknowledgments:}

The authors thank the communities of La Palma and El Castaño for their hospitality and all interviewees for their participation in our research. We thank Marta Borrós for developing the case study map and Sonia Graham for her comments on previous drafts of this article. We are also grateful to two anonymous reviewers for their comments on the first versions of this article. Laia d'Armengol acknowledges the financial support of the Catalan government's Research Agency ( AGAUR) through an individual grant, FI-DGR (2016-FI_B2-00047), and of Fundació Autònoma Solidària at UAB. Isabel Ruiz-Mallén also acknowledges the financial support of the Spanish government's Research Agency through a Ramón y Cajal research fellowship (RYC-2015-17676). Laia d'Armengol and Esteve Corbera also acknowledge that this work contributes to the ICTA-UAB María de Maeztu Unit of Excellence (MDM2015-0552).

\section{Data Availability:}

The data that support the findings of this study are available on request from the corresponding author, $L . d$. $C$. The data are not publicly available they contain information that could compromise the privacy of research participants.

\section{LITERATURE CITED}

Abel, N., H. Ross, and P. Walker. 1998. Mental models in rangeland research, communication and management. Rangeland Journal 20(1):77-91. https://doi.org/10.1071/RJ9980077

Ansell, C., and A. Gash. 2008. Collaborative governance in theory and practice. Journal of Public Administration Research and Theory 18(4):543-571. https://doi.org/10.1093/jopart/mum032

Armitage, D., A. Dzyundzyak, J. Baird, Ö. Bodin, R. Plummer, and L. Schultz. 2018. An approach to assess learning conditions, effects and outcomes in environmental governance. Environmental Policy and Governance 28(1):3-14. https://doi.org/10.1002/ eet.1781

Armitage, D., M. Marschke, and R. Plummer. 2008. Adaptive comanagement and the paradox of learning. Global Environmental Change 18(1):86-98. https://doi.org/10.1016/j.gloenvcha.2007.07.002

Baird, J., R. Plummer, and Ö. Bodin. 2016. Collaborative governance for climate change adaptation in Canada: experimenting with adaptive co-management. Regional Environmental Change 16:747-758. https://doi.org/10.1007/ $\underline{\text { s10113-015-0790-5 }}$

Berkes, F. 2009. Evolution of co-management: role of knowledge generation, bridging organizations and social learning. Journal of Environmental Management 90(5):1692-1702. https://doi.org/10.1016/ j.jenvman.2008.12.001
Berkes, F. 2010. Devolution of environment and resources governance: trends and future. Environmental Conservation 37 (4):489-500. https://doi.org/10.1017/s037689291000072x

Bouwen, R., and T. Taillieu. 2004. Multi-party collaboration as social learning for interdependence: Developing relational knowing for sustainable natural resource management. Journal of Community and Applied Social Psychology 14(March):137-153. https://doi.org/10.1002/casp.777

Carlsson, L. 2000. Policy networks as collective action. Policy Studies Journal 28(3):502-520. https://doi.org/10.1111/j.1541-0072.2000. tb02045.x

Comisión Nacional de Acuacultura y Pesca (CONAPESCA). 2015. Registro anual de explotación. CONAPESCA, Las Varas, Mexico.

Contreras, F. 2010. Ecosistemas costeros mexicanos: una actualización. Universidad Autónoma Metropolitana, Unidad Iztapalapa, México DF, Mexico.

d'Armengol, L., M. Prieto Castillo, I. Ruiz-Mallén, and E. Corbera. 2018. A systematic review of co-managed small-scale fisheries: social diversity and adaptive management improve outcomes. Global Environmental Change 52:212-225. https://doi. org/10.1016/j.gloenvcha.2018.07.009

Daw, T. M. 2008. How fishers count: engaging with fishers' knowledge in fisheries science and management. Dissertation. Newcastle University, Newcastle upon Tyne, UK. [online] URL: https://theses.ncl.ac.uk/jspui/bitstream/10443/114/1/daw08.pdf

Diduck, A., N. Bankes, D. Clark, and D. Armitage. 2005. Unpacking social learning in social-ecological systems: case studies of polar bear and narwhal management in northern Canada. Pages 269-290 in F. Berkes, R. Huebert, H. Fast, M. Manseau, and A. Diduck, editors. Breaking ice: renewable resource and ocean management in the Canadian north. Arctic Institute of North America and University of Calgary Press, Calgary, Alberta, Canada. https://doi.org/10.2307/j.ctv6gqvp5.20

Dray, A., P. Perez, N. Jones, C. Le Page, P. D'Aquino, I. White, and T. Auatabu. 2006. The AtollGame experience: from knowledge engineering to a computer-assisted role playing game. Journal of Artificial Societies and Social Simulations 9(1):6.

Etienne, M., D. R. Du Toit, and S. Pollard. 2008. ARDI : a coconstruction method for participatory modeling in natural resources management. Ecology and Society 16(1):44. https://doi. org/10.5751/ES-03748-160144

Evans, L., N. Cherrett, and D. Pemsl. 2011. Assessing the impact of fisheries co-management interventions in developing countries: a meta-analysis. Journal of Environmental Management 92(8):1938-1949. https://doi.org/10.1016/j.jenvman.2011.03.010

Fairweather, J. 2010. Farmer models of socio-ecologic systems: application of causal mapping across multiple locations. Ecological Modelling 221(3):555-562. https://doi.org/10.1016/j. ecolmodel.2009.10.026

Galafassi, D., T. M. Daw, L. Munyi, K. Brown, C. Barnaud, and I. Fazey. 2017. Learning about social-ecological trade-offs. Ecology and Society 22(1):2. https://doi.org/10.5751/ES-08920-220102 
Galafassi, D., T. M. Daw, M. Thyresson, S. Rosendo, T. Chaigneau, S. Bandeira, L. Munyi, I. Gabrielsson, and K. Brown. 2018. Stories in social-ecological knowledge cocreation. Ecology and Society 23(1):23. https://doi.org/10.5751/ES-09932-230123

García Lozano, A., H. Smith, and X. Basurto. 2019. Weaving governance narratives: discourses of climate change, cooperatives, and small-scale fisheries in Mexico. Maritime Studies 18(1):77-89. https://doi.org/10.1007/s40152-018-0125-5

Gómez González, A. E., E. Velázquez-Velázquez, R. RodilesHernández, A. A. González-Díaz, A. F. González-Acosta, and J. L. Castro-Aguirre. 2012. Lista sistemática de la ictiofauna de la Reserva de la Biosfera La Encrucijada, Chiapas, México. Revista Mexicana de Biodiversidad 83(3):674-686. https://doi.org/10.7550/ $\underline{\mathrm{rmb} .24468}$

Gutiérrez, N. L., R. Hilborn, and O. Defeo. 2011. Leadership, social capital and incentives promote successful fisheries. Nature 470:386-389. https://doi.org/10.1038/nature09689

Holling, C. S., editor. 1978. Adaptive environmental assessment and management. John Wiley, New York, New York, USA. [online] URL: http://pure.iiasa.ac.at/id/eprint/823/1/XB-78-103. pdf

Horowitz, J., R. L. Pressey, G. G. Gurney, A. S. Wenger, and K. A. Pahang. 2018. Investigating stakeholder perceptions of fish decline: making sense of multiple mental models. Sustainability 10(4):1222. https://doi.org/10.3390/su10041222

Instituto Nacional de Ecología. 1999. Programa de manejo Reserva de la Biosfera La Encrucijada, México. Instituto Nacional de Ecología, Mexico D.F., Mexico. [online] URL: http://www. paot.mx/centro/ine-semarnat/anp/AN09.pdf

Jones, N. A., H. Ross, T. Lynam, and P. Perez. 2014. Eliciting mental models: a comparison of interview procedures in the context of natural resource management. Ecology and Society 19 (1):13. https://doi.org/10.5751/ES-06248-190113

Jones, N. A., H. Ross, T. Lynam, P. Perez, and A. Leitch. 2011. Mental models: an interdisciplinary synthesis of theory and methods. Ecology and Society 16(1):46. https://doi.org/10.5751/ ES-03802-160146

Leach, M., and J. Fairhead. 2001. Plural perspectives and institutional dynamics: challenges for local forest management. International Journal of Agricultural Resources, Governance and Ecology 1(3/4):223-242. https://doi.org/10.1504/ijarge.2001.000013

Lundholm, C., and C. Stöhr. 2014. Stakeholder dialogues and shared understanding: the case of co-managing fisheries in Sweden. Sustainability 6:4525-4536. https://doi.org/10.3390/ $\underline{\mathrm{su} 6074525}$

Lynam, T., and K. Brown. 2012. Mental models in humanenvironment interactions: theory, policy implications, and methodological explorations. Ecology and Society 17(3):24. https://doi.org/10.5751/es-04257-170324

Mathevet, R., M. Etienne, T. Lynam, and C. Calvet. 2011. Water management in the Camargue Biosphere Reserve: insights from comparative mental model analysis. Ecology and Society 16(1):43. https://doi.org/10.5751/ES-04007-160143
Matulis, B. S., and J. R. Moyer. 2017. Beyond inclusive conservation: the value of pluralism, the need for agonism, and the case for social instrumentalism. Conservation Letters 10 (3):279-287. https://doi.org/10.1111/conl.12281

Oldekop, J. A., G. Holmes, W. E. Harris, and K. L. Evans. 2016. A global assessment of the social and conservation outcomes of protected areas. Conservation Biology 30(1):133-141. https://doi. org/10.1111/cobi.12568

Olsson, P., C. Folke, and T. Hahn. 2004. Social-ecological transformation for ecosystem management: the development of adaptive co-management of a wetland landscape in Southern Sweden. Ecology and Society 9(4):2. https://doi.org/10.5751/ ES-00683-090402

Özesmi, U., and S. Özesmi. 2003. A participatory approach to ecosystem conservation: fuzzy cognitive maps and stakeholder group analysis in Uluabat Lake, Turkey. Environmental Management 31(4):518-531. https://doi.org/10.1007/s00267-002-2841-1

Pahl-Wostl, C., and M. Hare. 2004. Processes of social learning in integrated resources management. Journal of Community and Applied Social Psychology 14:193-206. https://doi.org/10.1002/ casp. 774

Peterson, M. N., M. J. Peterson, and T. R. Peterson. 2006. Why conservation needs dissent. Conservation Biology 20(2):576-578. https://doi.org/10.1111/j.1523-1739.2006.00409.x

Rodríguez Perafán, C. A. 2014. Análisis multidimensional del aprovechamiento pesquero en el sistema estuarino de Chantuto Panzacola, Chiapas, México. Dissertation. El Colegio de la Frontera Sur, Mexico.

Romero-Berny, E. I., and C. A. Guichard-Romero. 2015. Antecedentes de un camino hacia la conservación. Page 304 in E. Velázquez-Velázquez, E. I. Romero-Berny, and G. RiveraVelázquez, editors. Reserva de la Biosfera La Encrucijada: dos décadas de investigación para su conservación. Universidad de Ciencias y Artes de Chiapas, Tuxtla Guitiérrez, Mexico.

Salliou, N., and C. Barnaud. 2017. Landscape and biodiversity as new resources for agro-ecology? Insights from farmers' perspectives. Ecology and Society 22(2):16. https://doi. org/10.5751/ES-09249-220216

Sandström, A. 2011. Social networks, joint image building, and adaptability: the case of local fishery management. Pages 288-321 in Ö. Bodin and C. Prell, editors. Social networks and natural resource management: uncovering the fabric of environmental governance. Cambridge University Press, Cambridge, UK. https://doi.org/10.1017/CBO9780511894985.013

Sandström, A., and C. Rova. 2010. Adaptive co-management networks: a comparative analysis of two fishery conservation areas in Sweden. Ecology and Society 15(3):14. https://doi. org/10.5751/es-03531-150314

Stone-Jovicich, S., T. Lynam, A. Leitch, and N. A. Jones. 2011. Using consensus analysis to assess mental models about water use and management in the Crocodile River Catchment, South Africa. Ecology and Society 16(1):45. https://doi.org/10.5751/ ES-03755-160145 
Suškevičs, M., T. Hahn, and R. Rodela. 2019. Process and contextual factors supporting action-oriented learning: a thematic synthesis of empirical literature in natural resource management. Society and Natural Resources 32(7):731-750. https://doi.org/10.1080/08941920.2019.1569287

Tran, T. A., J. Pittock, and L. A. Tuan. 2019. Adaptive comanagement in the Vietnamese Mekong Delta: examining the interface between flood management and adaptation. International Journal of Water Resources Development 35:326-342. https://doi.org/10.1080/07900627.2018.1437713

Vuillot, C., N. Coron, F. Calatayud, C. Sirami, R. Mathevet, and A. Gibon. 2016. Ways of farming and ways of thinking: do farmers' mental models of the landscape relate to their land management practices? Ecology and Society 21(1):35. https://doi. org/10.5751/ES-08281-210135

Young, E. 2001. State intervention and abuse of the commons: fisheries development in Baja California Sur, Mexico. Annals of the Association of American Geographers 91(2):283-306. https:// doi.org/10.1111/0004-5608.00244 
Appendix 1. Elicitation of mental models

A)

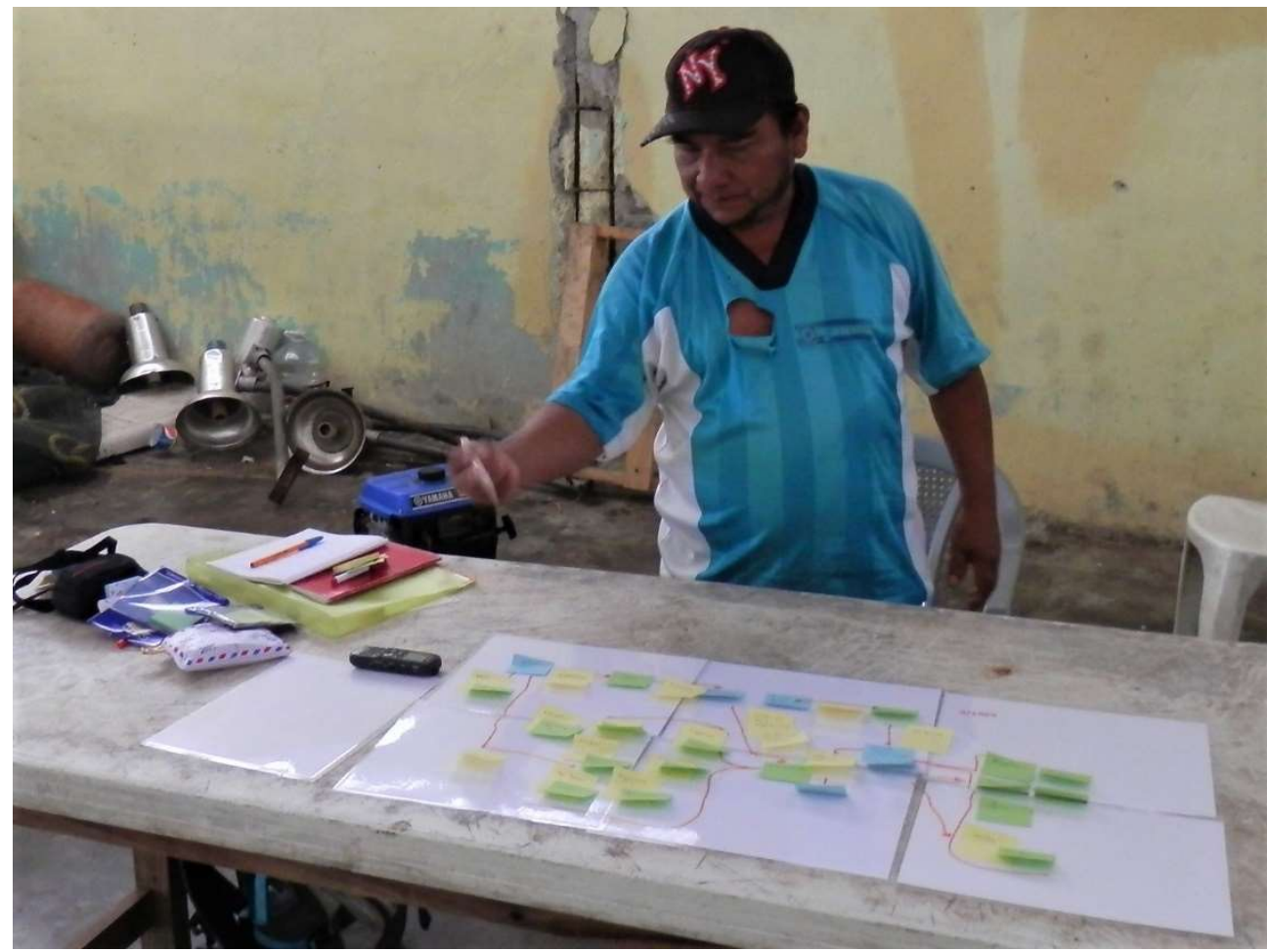

B)

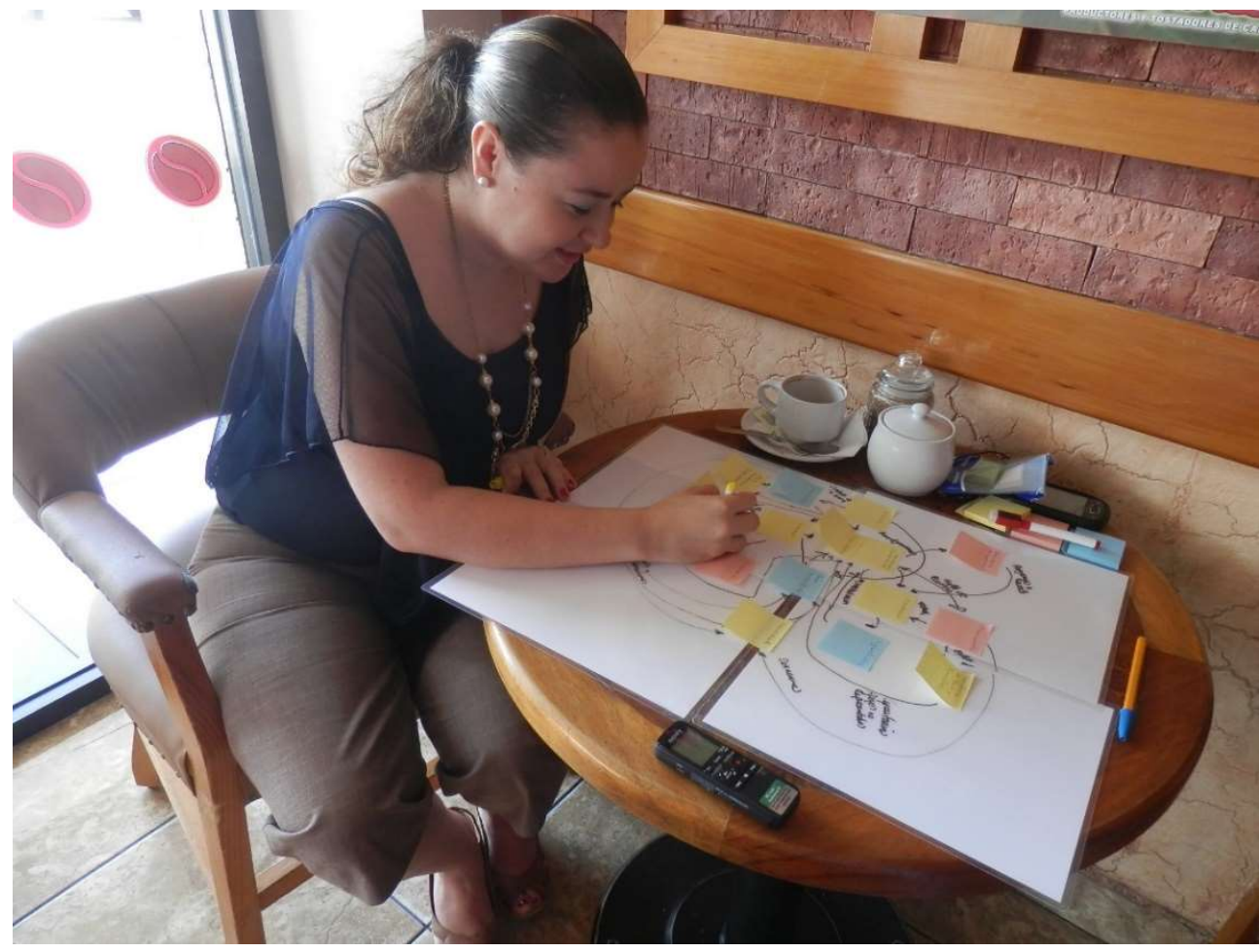

Fig. A1.1. Mental model drawing by A) a leader of a fishing cooperative, and B) a representative of an NGO. 


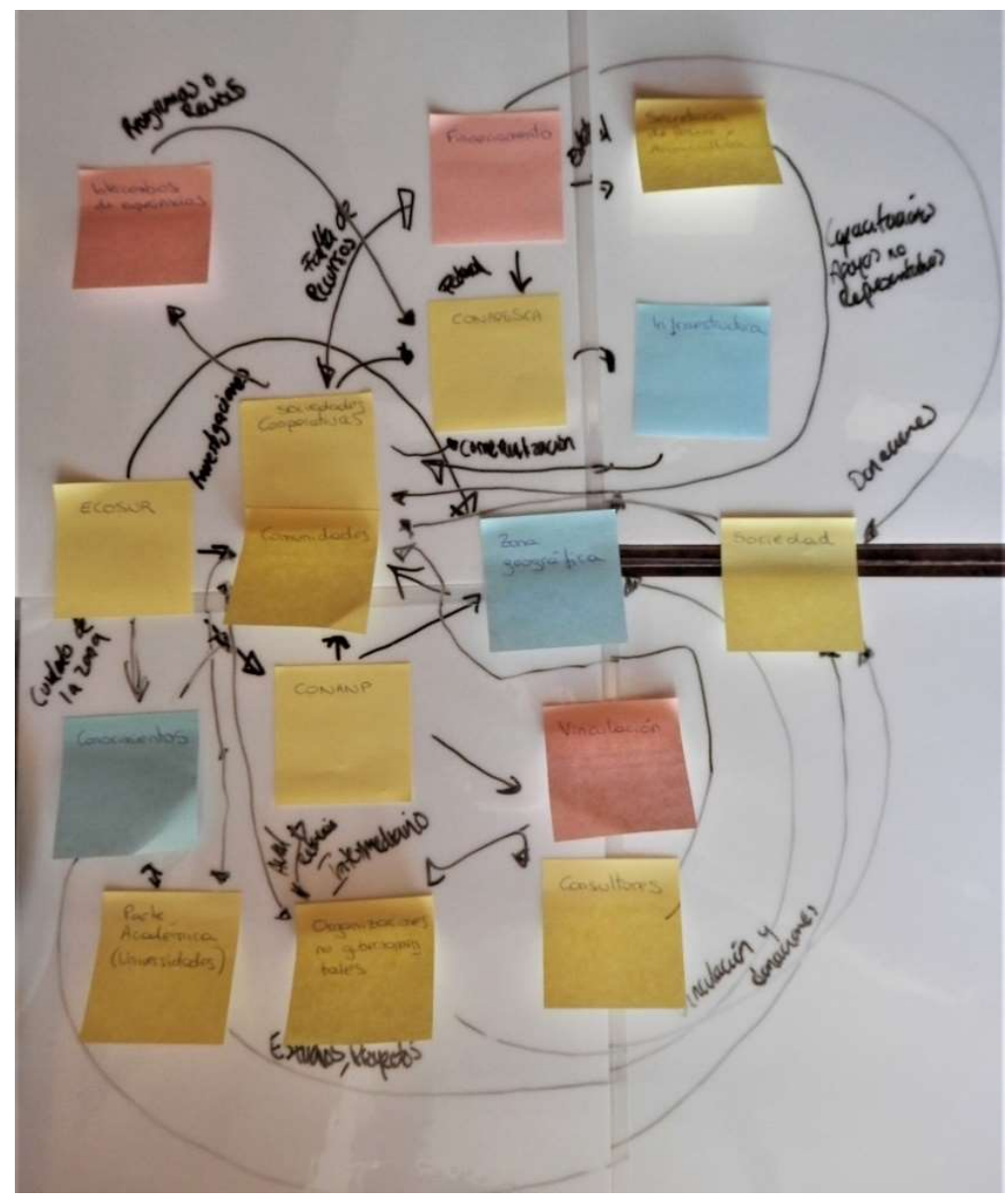

Fig. A1.2. Diagrammatic representation of a mental model. 
Appendix 2. Mental models' analysis

Table A2.1. Qualitative aggregation of actors

\begin{tabular}{|c|c|c|}
\hline Final concept & $\begin{array}{l}\text { Concepts in the IMMs that have been } \\
\text { homogenized }\end{array}$ & $\begin{array}{l}\text { Concepts in the IMMs that have been } \\
\text { aggregated }\end{array}$ \\
\hline Children & $\begin{array}{l}\text { Children } \\
\text { Kids } \\
\text { School children } \\
\text { Children or our children's children }\end{array}$ & Students + Fishers' children \\
\hline City councils & $\begin{array}{l}\text { City councils } \\
\text { Local government } \\
\text { Municipal fishery [department] }\end{array}$ & $\begin{array}{l}\text { City council of Acapetahua }+ \text { City } \\
\text { council of Mapastepec }\end{array}$ \\
\hline CONANP & $\begin{array}{l}\text { CONANP } \\
\text { CONANP - Reserve } \\
\text { CONANP La Encrucijada } \\
\text { La Encrucijada Biosphere Reserve } \\
\text { Reserve - CONANP } \\
\text { Reserve (Institute) } \\
\text { SEMARNAT } \\
\text { Those that organize (biologist) }\end{array}$ & $\begin{array}{l}\text { CONANP + La Encrucijada Biosphere } \\
\text { Reserve, } \\
\text { Biosphere Reserve + CONANP, } \\
\text { CONANP + Biologists, } \\
\text { Federal government + CONANP + } \\
\text { FANP + SEMARNAT }\end{array}$ \\
\hline CONAPESCA & $\begin{array}{l}\text { CONAPESCA } \\
\text { CONAPESCA's quarters } \\
\text { INAPESCA }\end{array}$ & $\begin{array}{l}\text { CONAPESCA + INAPESCA + CRIP, } \\
\text { CONAPESCA + SAGARPA, } \\
\text { CRIP + CONAPESCA, } \\
\text { Federal government + CONAPESCA } \\
\text { + INAPESCA, } \\
\text { INAPESCA + CONAPESCA }\end{array}$ \\
\hline $\begin{array}{l}\text { Cooperative } \\
\text { directives }\end{array}$ & $\begin{array}{l}\text { Cooperative } \\
\text { Cooperative administratives } \\
\text { Directives }\end{array}$ & \\
\hline Donors & $\begin{array}{l}\text { RARE } \\
\text { Society (for instance businessmen, } \\
\text { institutions, banks, nature lovers) } \\
\text { USAID }\end{array}$ & USAID + RARE \\
\hline Families & $\begin{array}{l}\text { Family } \\
\text { Fishers' families } \\
\text { Next generations }\end{array}$ & $\begin{array}{l}\text { Family }+ \text { Elders }+ \text { Wives }+ \text { Children }+ \\
\text { Schools }\end{array}$ \\
\hline $\begin{array}{l}\text { Federation of } \\
\text { cooperatives }\end{array}$ & $\begin{array}{l}\text { Soconusco's federation of } \\
\text { cooperatives }\end{array}$ & \\
\hline Fishers & $\begin{array}{l}\text { Cooperative } \\
\text { Cooperative men } \\
\text { Cooperatives } \\
\text { Cooperative society } \\
\text { Cooperative society's members and } \\
\text { directives } \\
\text { Fisher } \\
\text { Fishermen and fisherwomen } \\
\text { Fishers } \\
\text { Fishers and cooperative } \\
\text { [Cooperative] members } \\
\text { Men } \\
\text { Society } \\
\text { Society (all fishers) }\end{array}$ & $\begin{array}{l}\text { Cooperative + Cooperative directives, } \\
\text { Cooperative + Fishers } \\
\text { Cooperative + Fishers + 6-7 } \\
\text { cooperatives, } \\
\text { Cooperative societies + Communities, } \\
\text { Fishers + Adults, } \\
\text { Fishers + Cooperatives, } \\
\text { Fishers + Cooperatives + Dads, } \\
\text { Fishers + Members, } \\
\text { Open waters' fishers + Estuarine } \\
\text { fishers, } \\
\text { Fishing cooperatives + Fishers, } \\
\text { Teams + Working teams + } \\
\text { Cooperatives + Human beings, }\end{array}$ \\
\hline
\end{tabular}


Table A2.1. Continued

\begin{tabular}{|c|c|c|}
\hline $\begin{array}{l}\text { Fishers from other } \\
\text { cooperatives }\end{array}$ & $\begin{array}{l}\text { Cooperatives } \\
\text { Other cooperatives } \\
\text { People from other cooperatives } \\
\text { People from other places }\end{array}$ & \\
\hline $\begin{array}{l}\text { Governmental } \\
\text { organizations }\end{array}$ & $\begin{array}{l}\text { Government } \\
\text { Other institutions } \\
\text { Mexican state's departments }\end{array}$ & \\
\hline $\begin{array}{l}\text { Inter-cooperative } \\
\text { committee } \\
\text { NGOs }\end{array}$ & $\begin{array}{l}\text { Chanpanic } \\
\text { Responsible fishing committee } \\
\text { Acción Cultural Madre Tierra } \\
\text { Civil society organizations (ACMT) } \\
\text { Pronatura } \\
\text { RARE Madre Tierra }\end{array}$ & $\begin{array}{l}\text { Responsible fishing committee + } \\
\text { Facilitator, } \\
\text { CASFA + ACMT, } \\
\text { Madre Tierra + CASFA, } \\
\text { Razonatura + ACMT + CASFA }\end{array}$ \\
\hline Research centres & $\begin{array}{l}\text { Academics } \\
\text { ECOSUR } \\
\text { Institutions of scientific research } \\
\text { Scientific-technical side } \\
\text { UNICACH }\end{array}$ & $\begin{array}{l}\text { ECOSUR + Academic side } \\
\text { (universities), } \\
\text { UNICACH + UNACH + ECOSUR }\end{array}$ \\
\hline $\begin{array}{l}\text { Responsible } \\
\text { fishing } \\
\text { SEPESCA }\end{array}$ & $\begin{array}{l}\text { Responsible fishing } \\
\text { Those that come } \\
\text { Fishery Department } \\
\text { Fishery and Aquaculture Department } \\
\text { SEPESCA } \\
\text { SEPESCA's quarters } \\
\text { State's government }\end{array}$ & \\
\hline $\begin{array}{l}\text { Trade } \\
\text { intermediaries }\end{array}$ & $\begin{array}{l}\text { Coyote } \\
\text { Trader }\end{array}$ & \\
\hline
\end{tabular}


Table A2.2. Qualitative aggregation of resources

\begin{tabular}{|c|c|c|}
\hline Final concept & $\begin{array}{l}\text { Concepts in the IMMs that have been } \\
\text { homogenized }\end{array}$ & $\begin{array}{l}\text { Concepts in the IMMs that have been } \\
\text { aggregated }\end{array}$ \\
\hline Agreements & $\begin{array}{l}20 \text { agreements } \\
\text { Agreements } \\
\text { Inter-cooperative agreements } \\
\text { Internal agreements } \\
\text { To agree }\end{array}$ & $\begin{array}{l}\text { Rules }+ \text { Resolution of the use of } \\
\text { fishing gears, } \\
20 \text { agreements }+[\text { listing of several of } \\
\text { the } 20 \text { agreements }]\end{array}$ \\
\hline Fish stock & $\begin{array}{l}\text { Fish } \\
\text { Fish and shrimp } \\
\text { Fish species } \\
\text { Fishery resource } \\
\text { Fishery resources } \\
\text { Resource } \\
\text { Species }\end{array}$ & $\begin{array}{l}\text { Big fish + Biological resource (eggs), } \\
\text { Fish + Crab, } \\
\text { Future harvest + Little fish }\end{array}$ \\
\hline Fish with roe & $\begin{array}{l}\text { Animals with roe } \\
\text { Fish with roe } \\
\text { Product with roe }\end{array}$ & $\begin{array}{l}\text { Flathead grey mullet with roe }+ \\
\text { Cichlids with roe }\end{array}$ \\
\hline Funding & $\begin{array}{l}\text { Economic resources } \\
\text { Funds and financial resources } \\
\text { Money } \\
\text { Supports } \\
\text { Temporary jobs } \\
\text { Temporary work }\end{array}$ & $\begin{array}{l}\text { Fishing infrastructure, motors + Social } \\
\text { support for social peace during the six } \\
\text { months of low season + Fishing gears, } \\
\text { Resource + economy, } \\
\text { Resources + Temporary jobs, } \\
\text { Resources + Temporary work, } \\
\text { Supports + Economic resources, } \\
\text { Supports + Nets + SEPESCA's annual } \\
\text { support + Temporary jobs + } \\
\text { Resources, } \\
\text { Temporary jobs + Economically }\end{array}$ \\
\hline Future & $\begin{array}{l}\text { Future } \\
\text { (Living better) in future } \\
\text { Thinking in tomorrow } \\
\text { Tomorrow's day }\end{array}$ & \\
\hline Habitat & $\begin{array}{l}\text { Environment } \\
\text { Lagoons } \\
\text { Mangroves } \\
\text { Nature (trees, estuaries, sea) } \\
\text { Water }\end{array}$ & Fauna and flora + Mangrove \\
\hline Harvest & $\begin{array}{l}\text { Good production } \\
\text { Permanent production } \\
\text { Product } \\
\text { Production }\end{array}$ & Production + Sized fishable product \\
\hline Illegal gears & $\begin{array}{l}\text { Forbidden gears } \\
\text { [Shrimp] shelter }\end{array}$ & Forbidden fishing gears + Stow net \\
\hline Infrastructure & $\begin{array}{l}\text { Ice machine and cooperative's } \\
\text { facilities }\end{array}$ & Money for buying motors + Nets, \\
\hline Juveniles & $\begin{array}{l}\text { [Catch] big fish } \\
\text { [Catch more] fish with ideal size and } \\
\text { weight } \\
\text { Juvenile product } \\
\text { Product } \\
\text { Small fish } \\
\text { Small species }\end{array}$ & $\begin{array}{l}\text { [Catch more] fish with commercial } \\
\text { size }+[\text { Release }] \text { small fish }\end{array}$ \\
\hline
\end{tabular}


Table A2.2. Continued

\begin{tabular}{|c|c|c|}
\hline Knowledge & $\begin{array}{l}\text { Information } \\
\text { Knowledge } \\
\text { Knowledges } \\
\text { Research } \\
\text { Socio-economic studies of the } \\
\text { concession } \\
\text { Research, validate }\end{array}$ & \\
\hline Natural resources & $\begin{array}{l}\text { Animals } \\
\text { Environment, nature and trees } \\
\text { Flora and fauna } \\
\text { Mangroves } \\
\text { Species (fish and other animals) } \\
\text { The natural environment }\end{array}$ & $\begin{array}{l}\text { Birds + Crocodiles + Mangrove, } \\
\text { Environment, Flora and fauna and } \\
\text { ecologic equilibrium + Crocodile, } \\
\text { Hydric connectivity + Birds + Forest + } \\
\text { Ecological diversity + Non- } \\
\text { commercial species + Mammals + } \\
\text { Natural resources, } \\
\text { Nature (trees, estuaries, sea) + } \\
\text { Resource found here, } \\
\text { Water resources + Fauna (mammals } \\
\text { and birds) + Wood resources } \\
\text { (mangrove, tulares, popales), } \\
\text { Wood + Wild fauna and birds, }\end{array}$ \\
\hline $\begin{array}{l}\text { No-take areas and } \\
\text { closed seasons }\end{array}$ & $\begin{array}{l}\text { Areas } \\
\text { Closed lagoons } \\
\text { Closed seasons } \\
\text { No-take areas }\end{array}$ & $\begin{array}{l}\text { Closed seasons + No-take areas, } \\
\text { Forbidden areas + Closed season, } \\
\text { No-take areas + Closed seasons, } \\
\text { No-take areas + Local closed seasons, }\end{array}$ \\
\hline $\begin{array}{l}\text { Responsible } \\
\text { fishing }\end{array}$ & $\begin{array}{l}\text { Fishing with responsibility } \\
\text { Fishing with responsibility and care } \\
\text { Program } \\
\text { Respect, make the activity responsibly } \\
\text { Responsible fishing } \\
\text { Responsible fishing process } \\
\text { Responsible fishing program } \\
\text { Responsible fishing project } \\
\text { The fishing they know, the responsible } \\
\text { fishing }\end{array}$ & $\begin{array}{l}\text { Fishing with responsibility }+ \text { They talk } \\
\text { about responsible fishing }\end{array}$ \\
\hline
\end{tabular}


Table A2.3. Qualitative aggregation of actions

\begin{tabular}{|c|c|c|}
\hline Final concept & $\begin{array}{l}\text { Concepts in the IMMs that have been } \\
\text { homogenized }\end{array}$ & $\begin{array}{l}\text { Concepts in the IMMs that have been } \\
\text { aggregated }\end{array}$ \\
\hline Capacity building & $\begin{array}{l}\text { Courses } \\
\text { Talks } \\
\text { Train } \\
\text { Training } \\
\text { Trainings } \\
\text { Workshop }\end{array}$ & $\begin{array}{l}\text { Consultancy + Courses, } \\
\text { Courses + Events + Exchange of } \\
\text { experiences, sport events + cayuco races, } \\
\text { Courses + Learn, } \\
\text { Games + Tournaments for motivation, } \\
\text { Talks + Workshops, } \\
\text { Training + Exchange of experiences, } \\
\text { Trainings + Teach how to participate in } \\
\text { assemblies, }\end{array}$ \\
\hline Commercialization & Joint commercialization & $\begin{array}{l}\text { Cool box + Very good quality + Selling + } \\
\text { Favourable market + Better price, } \\
\text { Commercialization + Products, } \\
\text { Differentiate, certificate + Product quality } \\
+ \text { Improve post-harvest processes to add in } \\
\text { situ value + Improve commercialization } \\
\text { processes, } \\
\text { Generating added value + Better harvest } \\
\text { registration + Better facilities + Better } \\
\text { prices, } \\
\text { Improving + Price, } \\
\text { Integrating company + Organic certificate } \\
+ \text { Filleting + Fish transformation + Fish } \\
\text { added value, } \\
\text { Joint commercialization + Product } \\
\text { classification + Cool box, Good price, } \\
\text { Increase value + Marketing to better } \\
\text { markets, } \\
\text { Product's size and weight + Prices, } \\
\text { Projects + Cool boxes + Premise + Fridge } \\
+ \text { Offices + Selling to international and } \\
\text { local market, } \\
\text { Selling + Product, } \\
\text { Selling + Product with quality + Direct } \\
\text { marketing + Market or restaurant, }\end{array}$ \\
\hline Endorsement & $\begin{array}{l}\text { Accompaniment and support } \\
\text { Validation } \\
\text { Guidance }\end{array}$ & $\begin{array}{l}\text { Accompaniment }+ \text { Endorsement }+ \\
\text { Reference }+ \text { Credibility }\end{array}$ \\
\hline Preserve & $\begin{array}{l}\text { Care } \\
\text { Respect }\end{array}$ & $\begin{array}{l}\text { Care, respect }+ \text { Control through } \\
\text { Environmental Management Unities, } \\
\text { To do not finish up + Work harmoniously, }\end{array}$ \\
\hline Surveillance & $\begin{array}{l}\text { Monitoring } \\
\text { Monitoring respect } \\
\text { Supervision tours } \\
\text { Surveillance }\end{array}$ & $\begin{array}{l}\text { Surveillance }+ \text { Monitoring and surveillance } \\
\text { tours }+ \text { Water quality, fish size }+ \text { Fishing } \\
\text { gears that meet the rules }\end{array}$ \\
\hline
\end{tabular}


Appendix 3. Individual mental models

a) Coop1

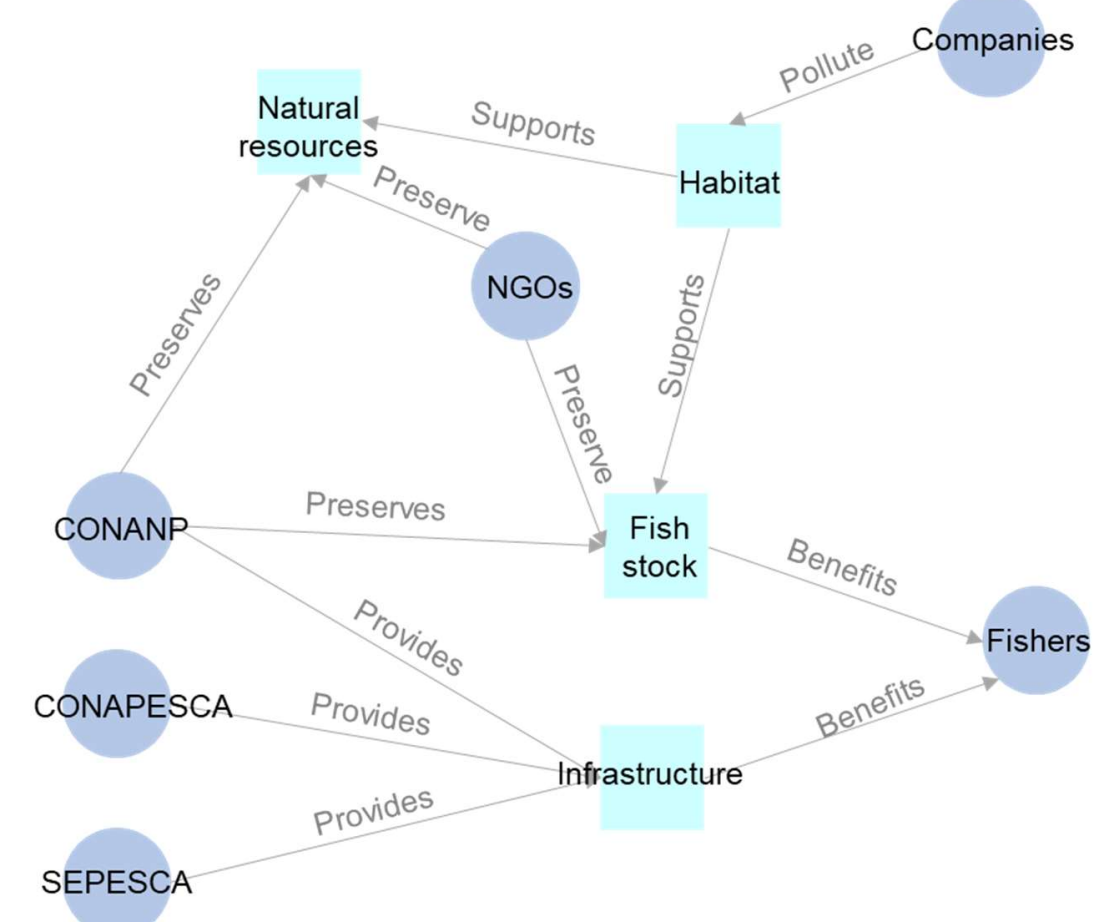

b) Coop2

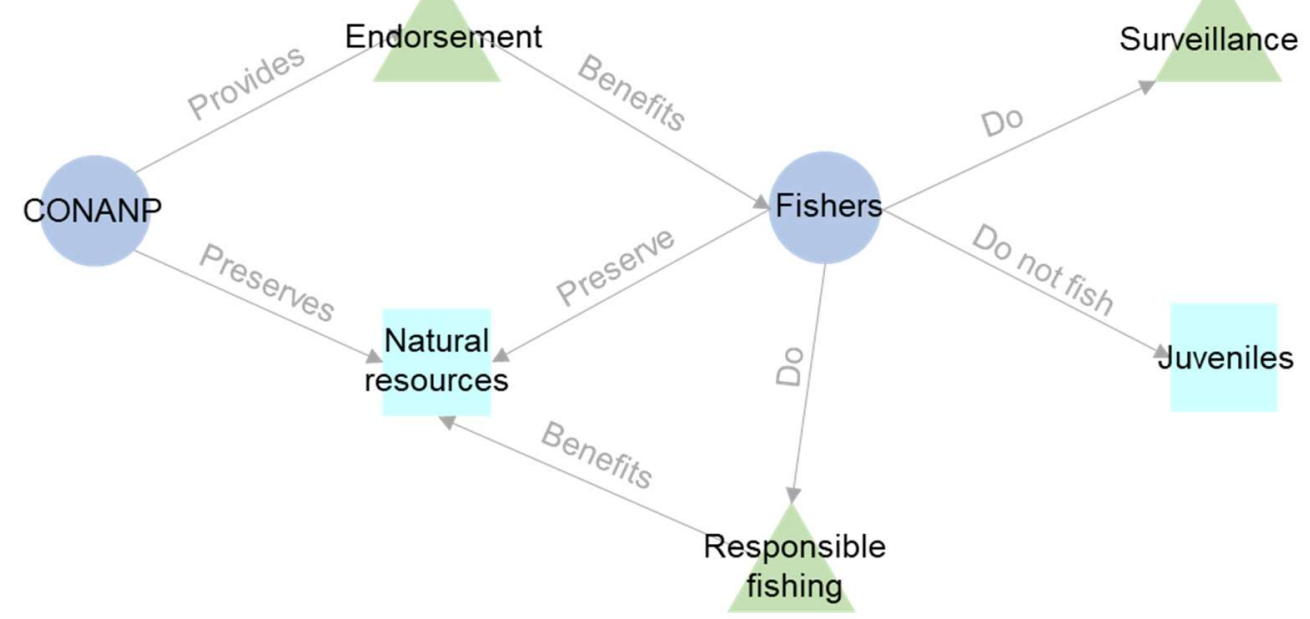


c) Coop3 (LaPa4)

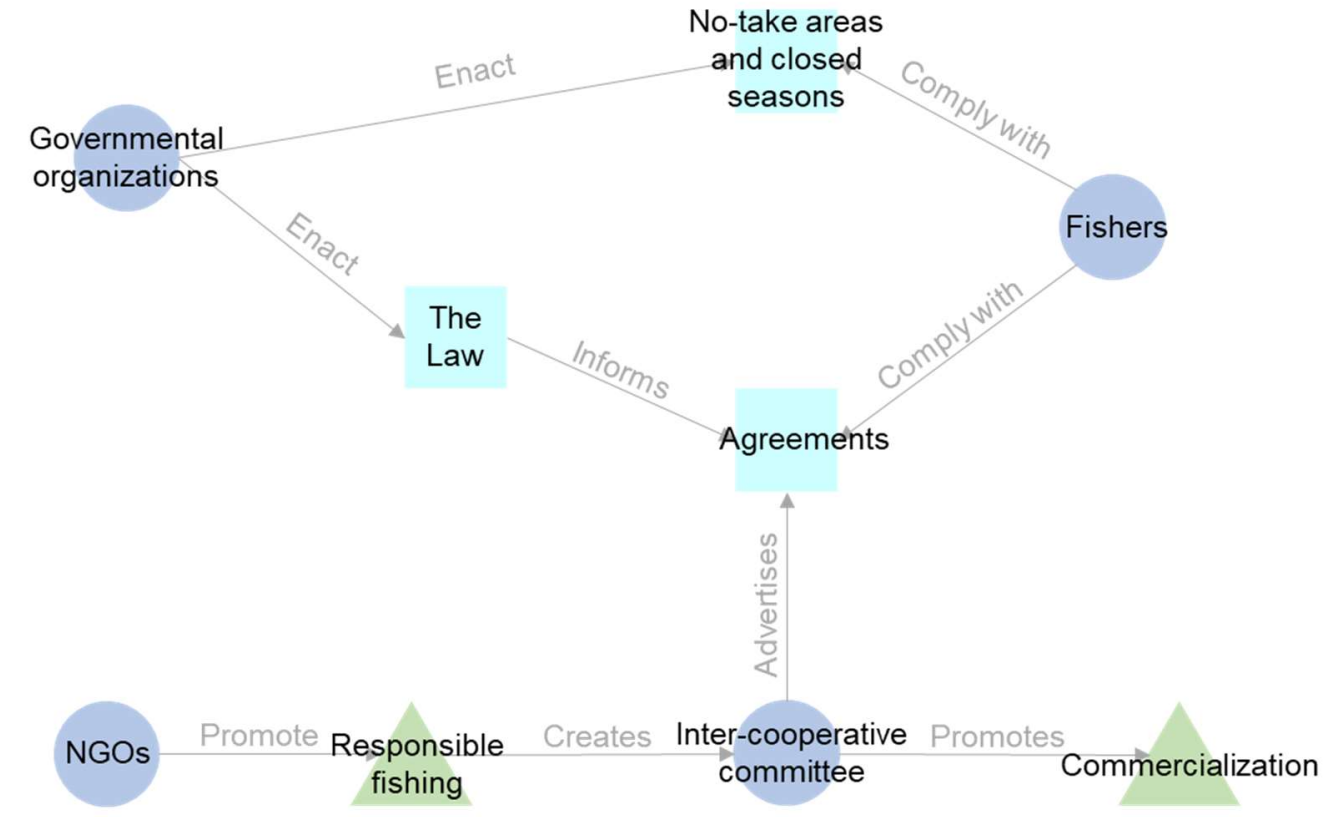

d) Coop4

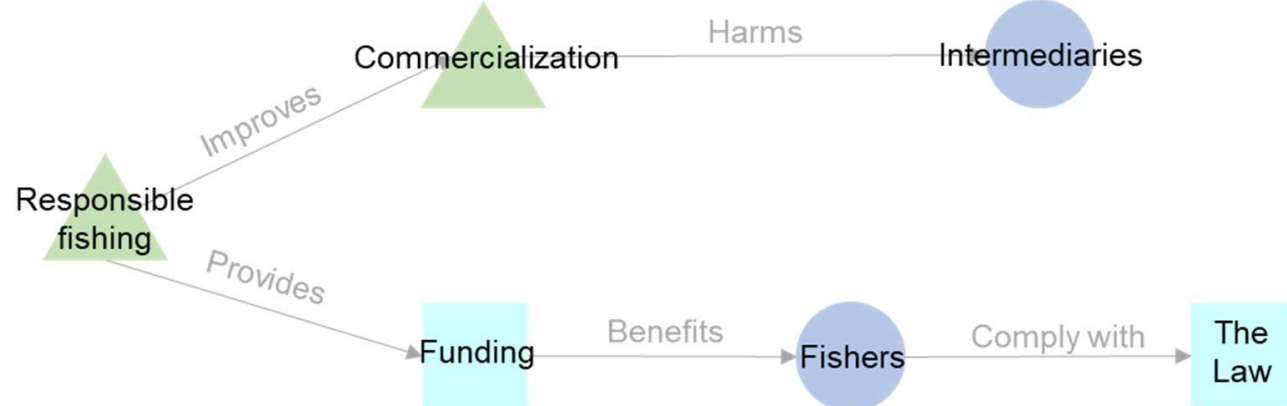


e) Coop5 (LuCa10)

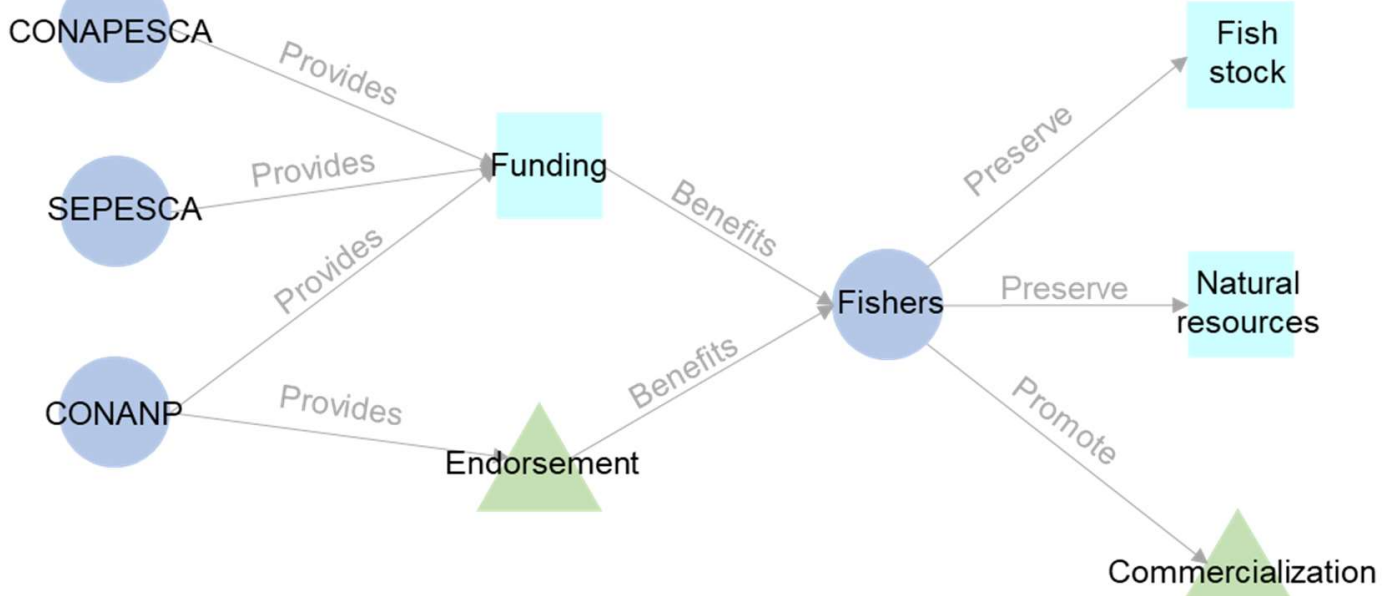

e) Coop6

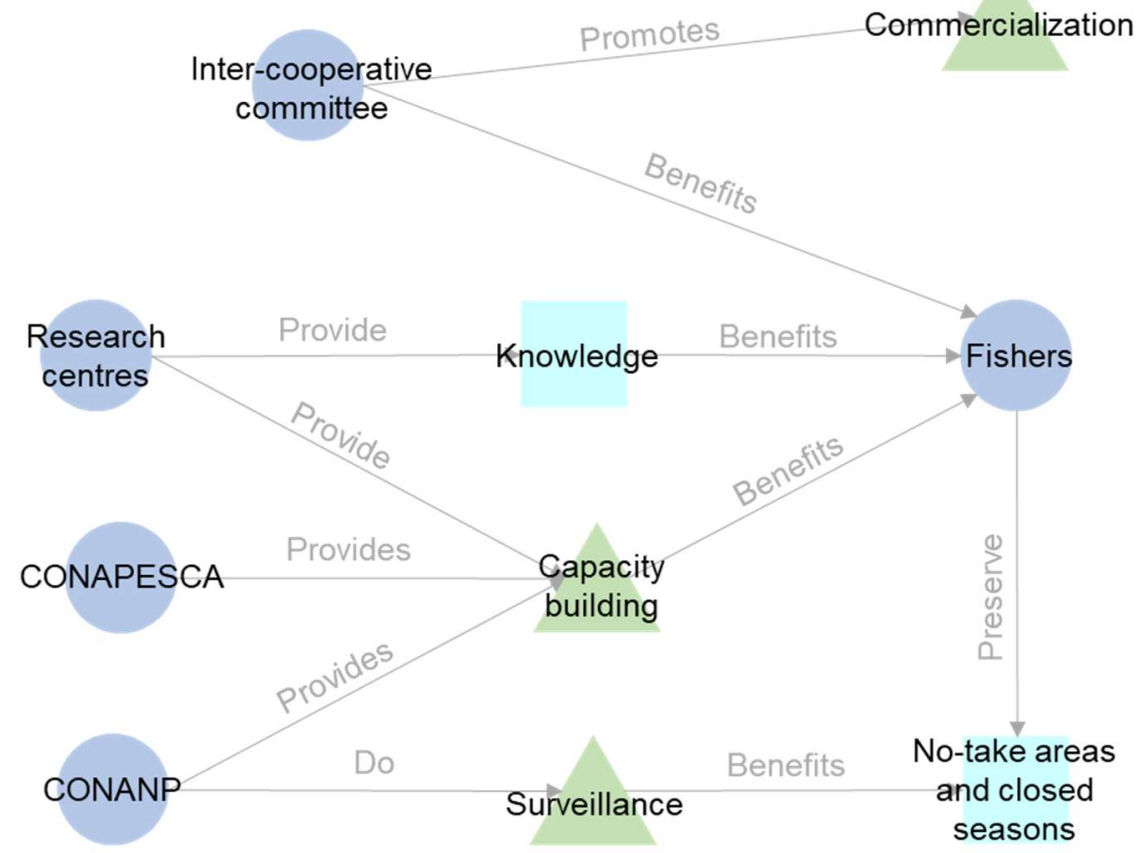


Legend

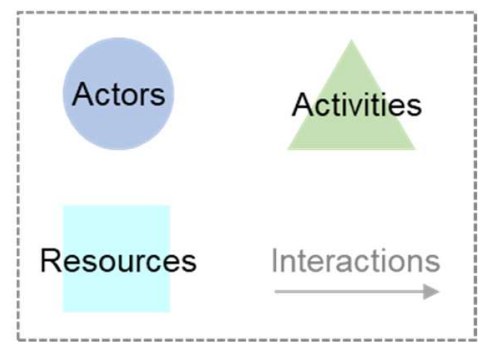

Fig. A3.1. Individual mental models of the leaders of six fishing cooperatives

a) LaPa1

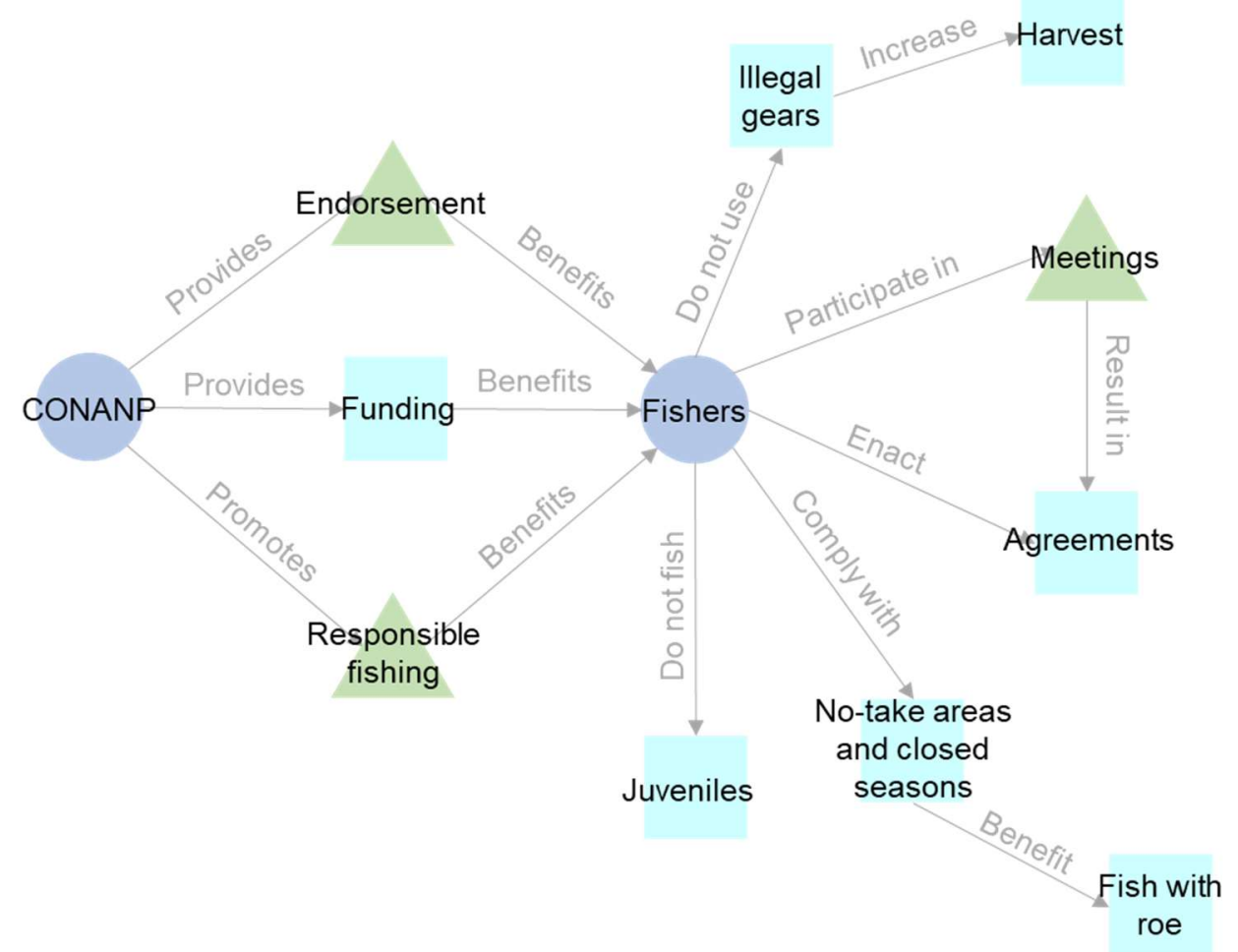


b) $\mathrm{LaPa} 2$

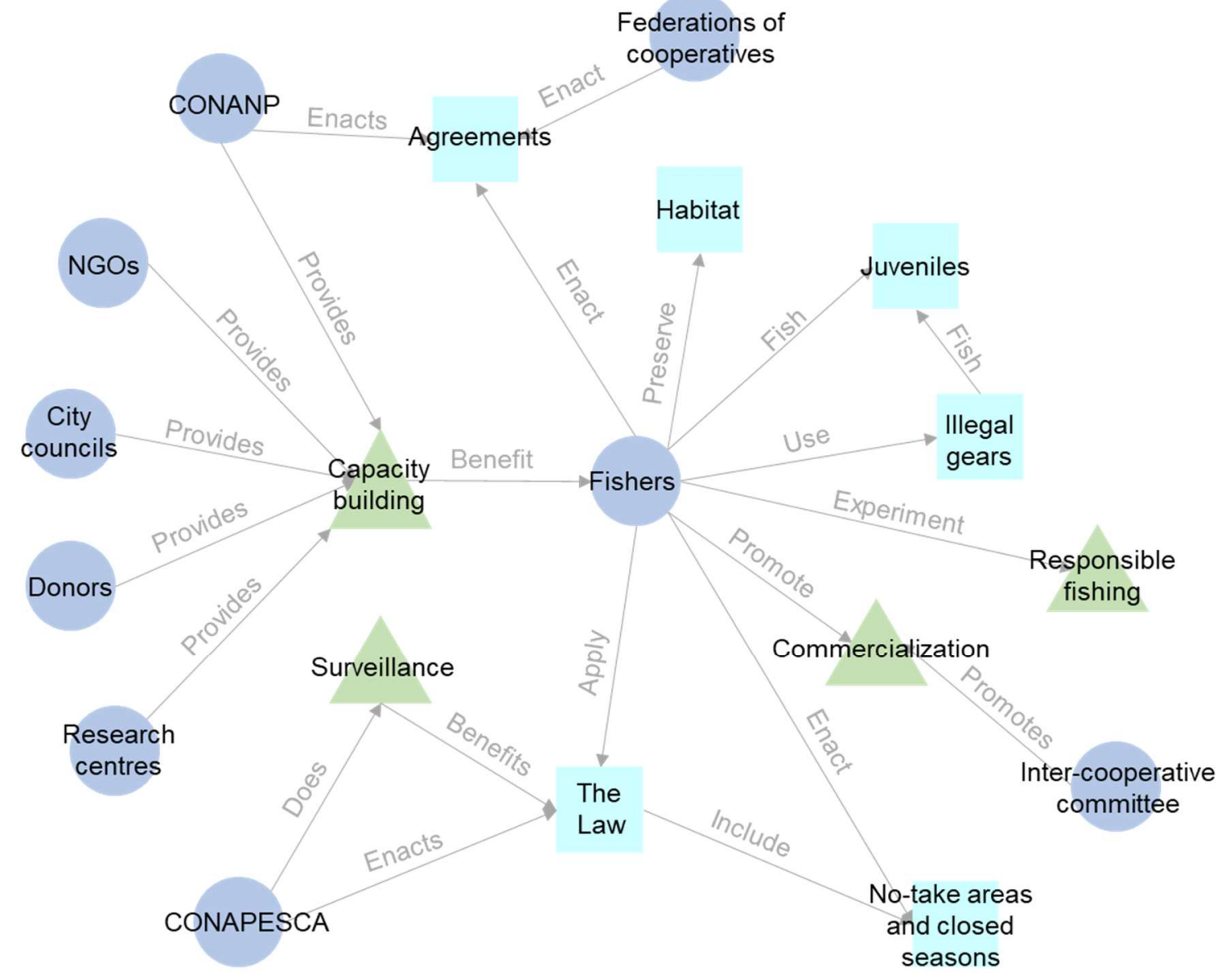

c) $\mathrm{LaPa} 3$

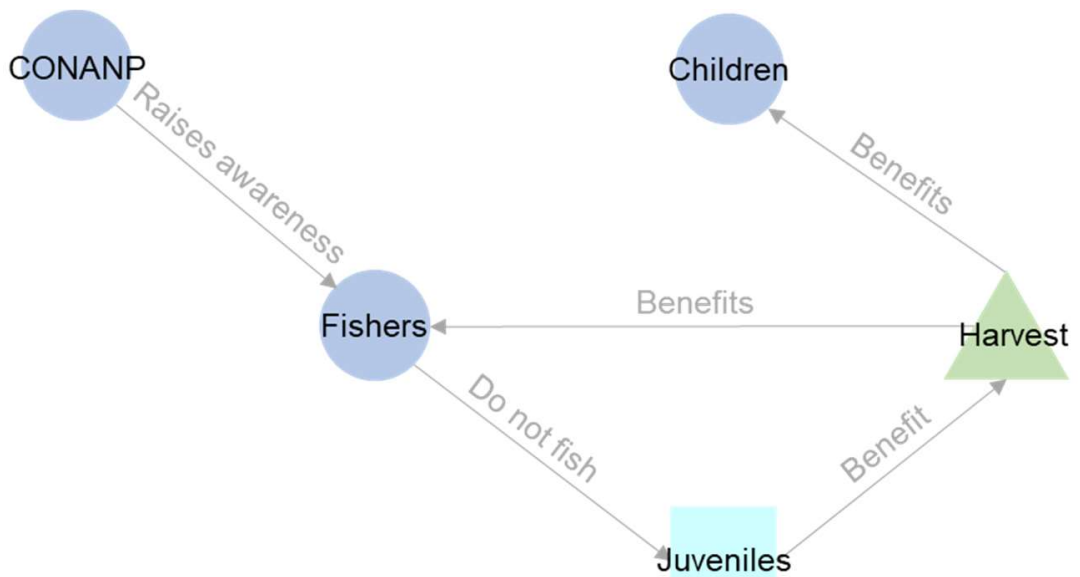


d) LaPa4 (Coop3)

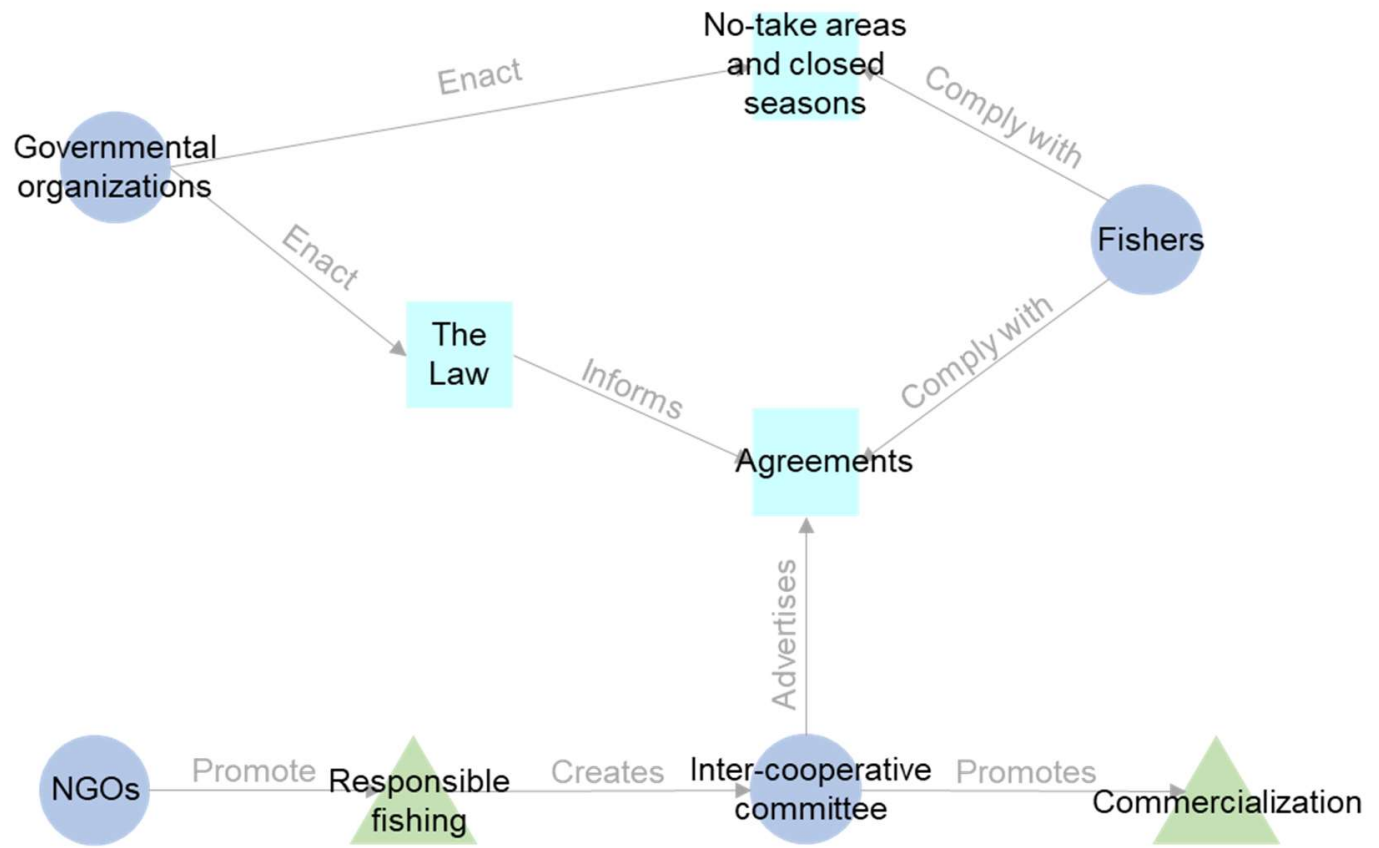


e) LaPa5

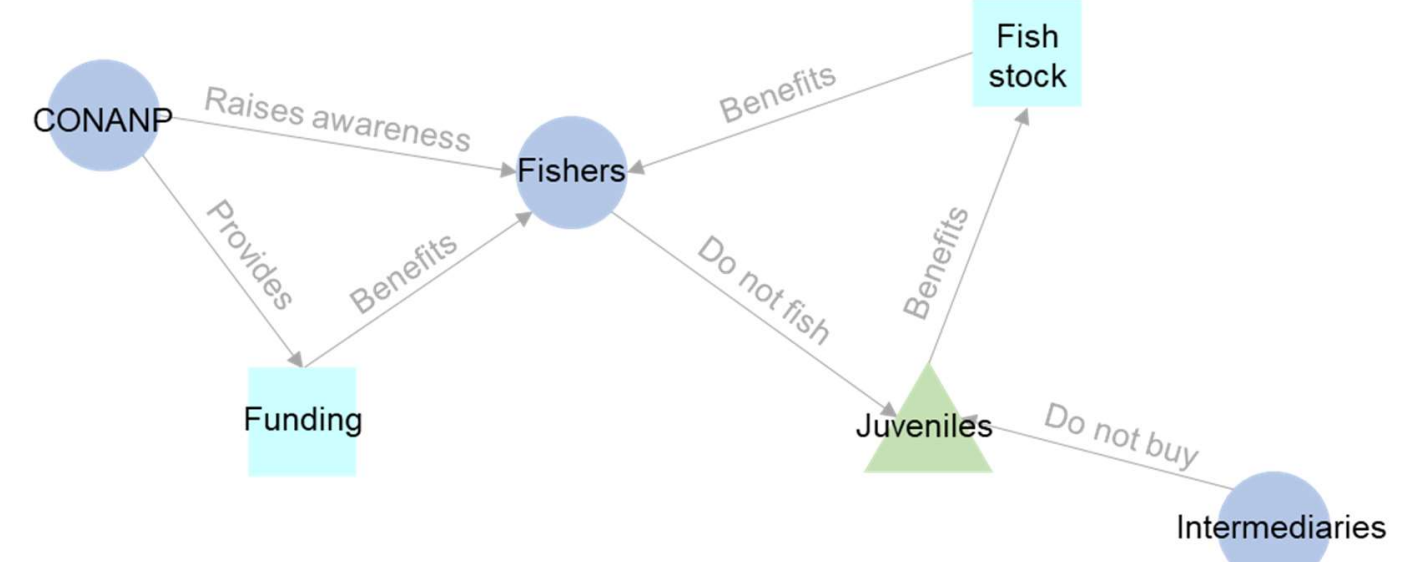

f) $\mathrm{LaPa} 6$

Fishers Do not fish Juveniles Benefit Commercialization

g) $\mathrm{LaPa} 7$

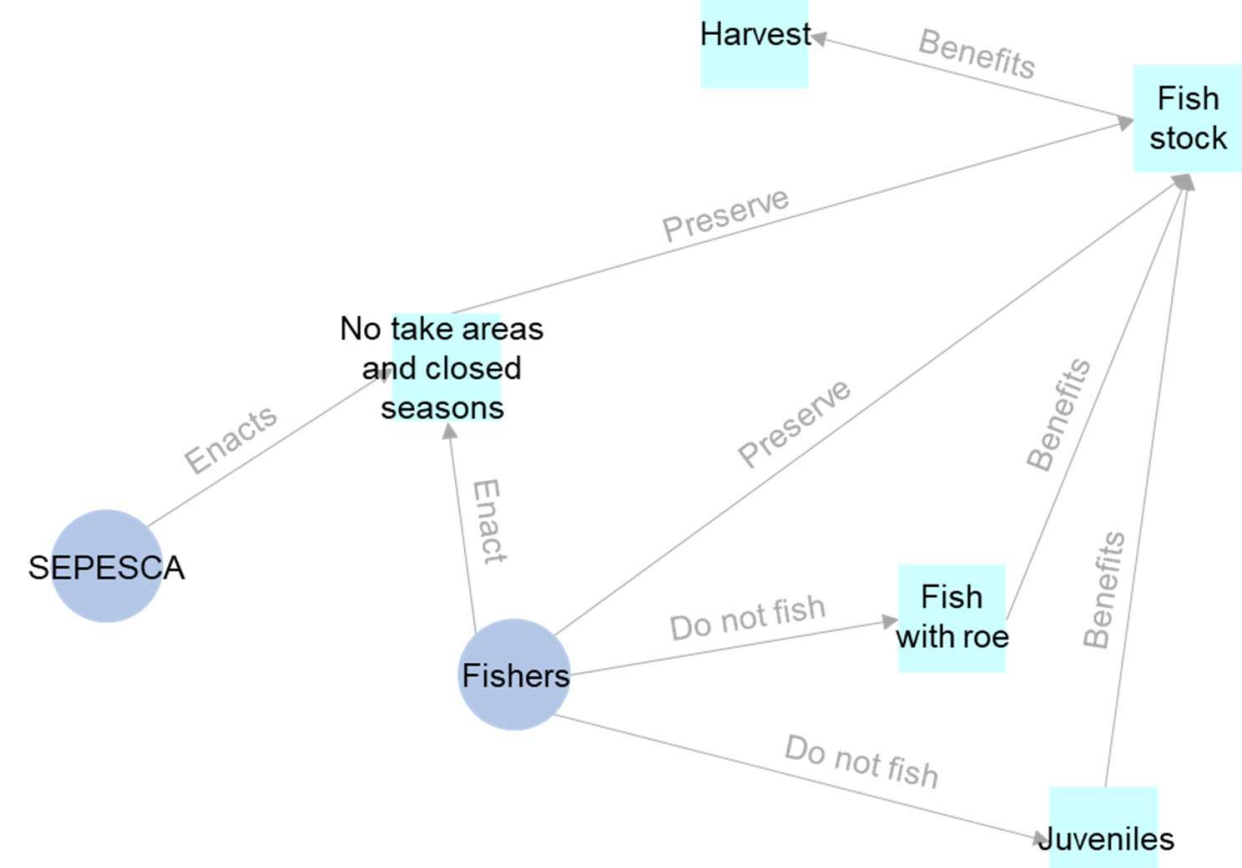


h) LaPa8

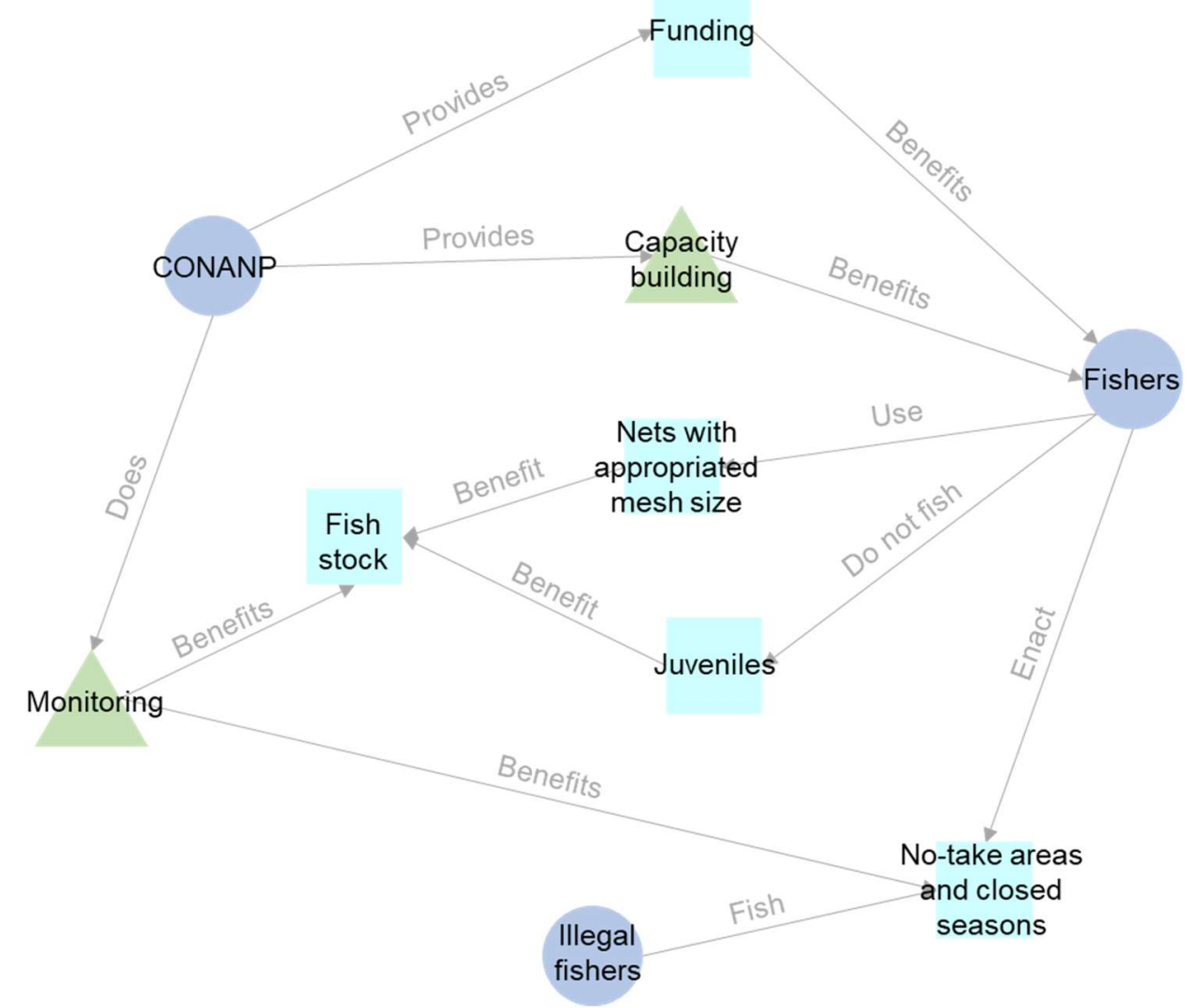

Legend

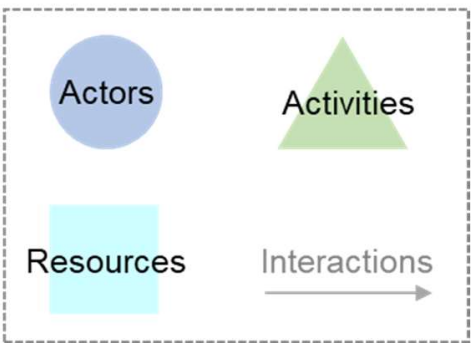

Fig. A3.2. Individual mental models of eight members of La Palma fishing cooperative 
a) LuCa01

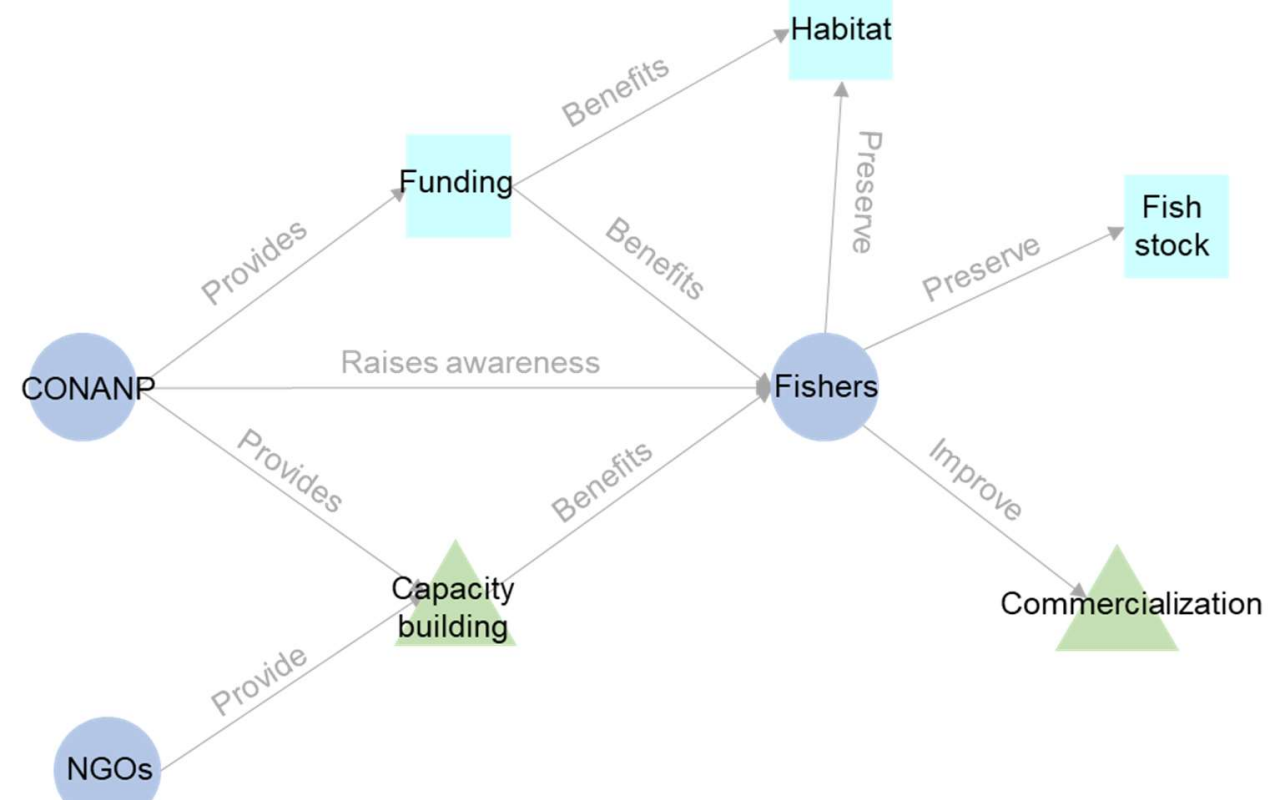

b) LuCa02

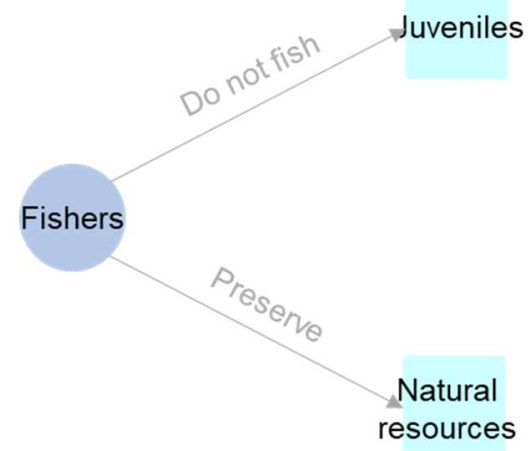


c) $\mathrm{LuCaO}$

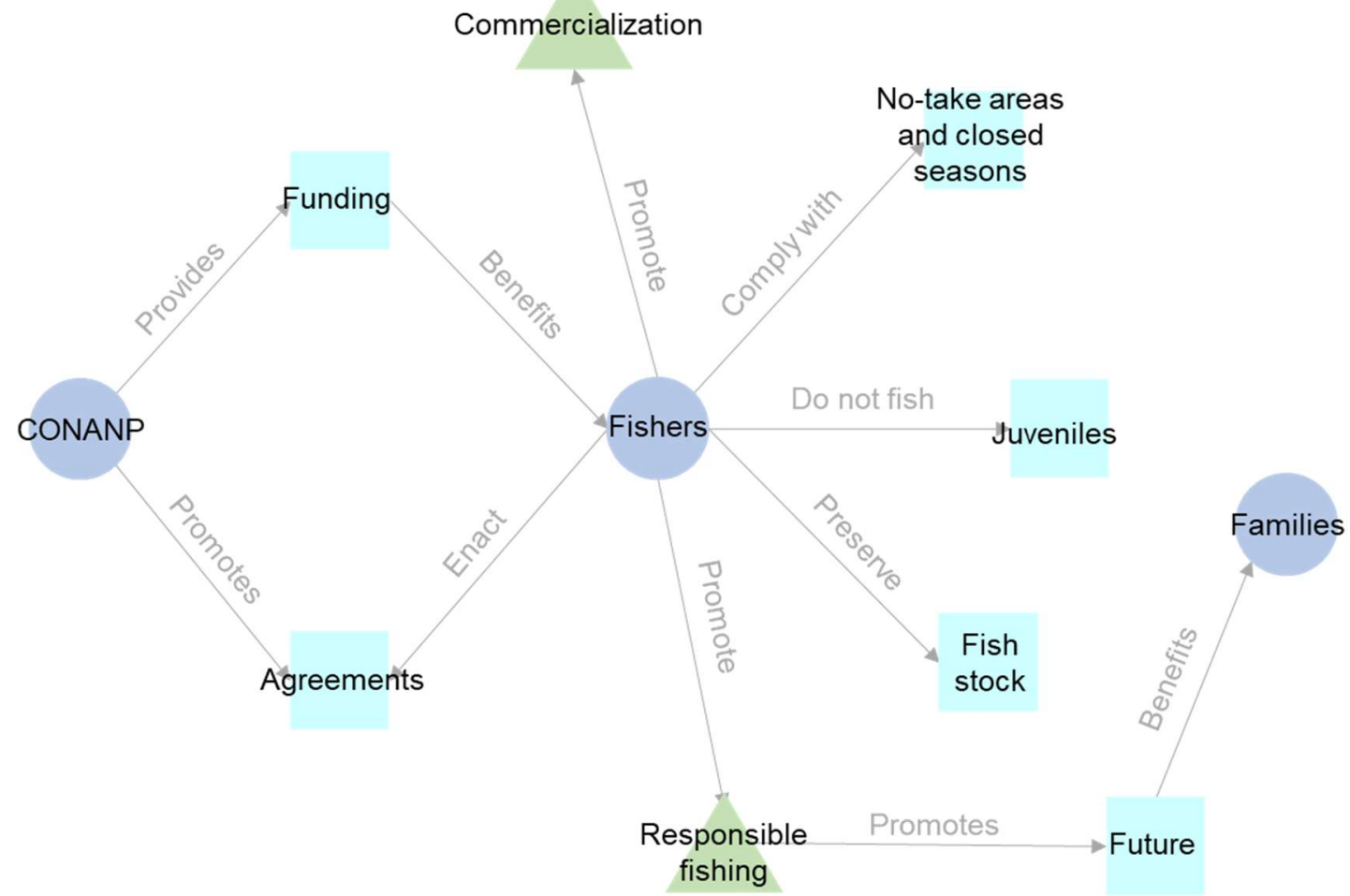

d) $\mathrm{LuCaO}_{4}$

Governmental
organizations

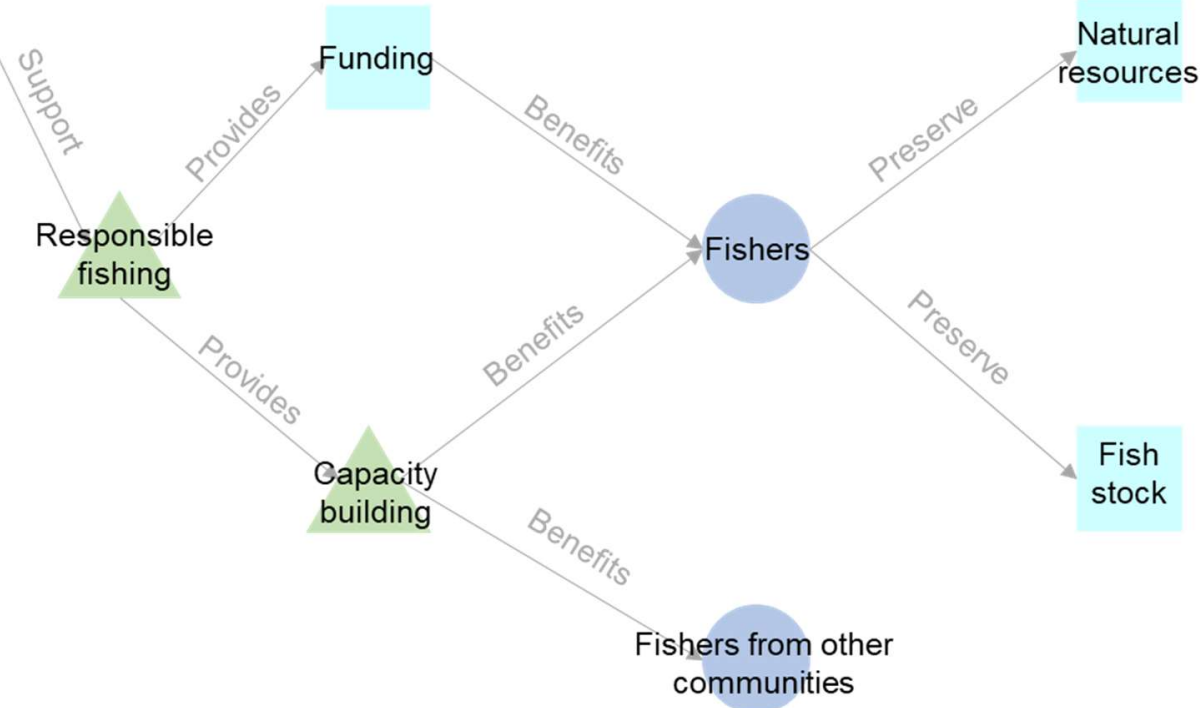


e) LuCa05

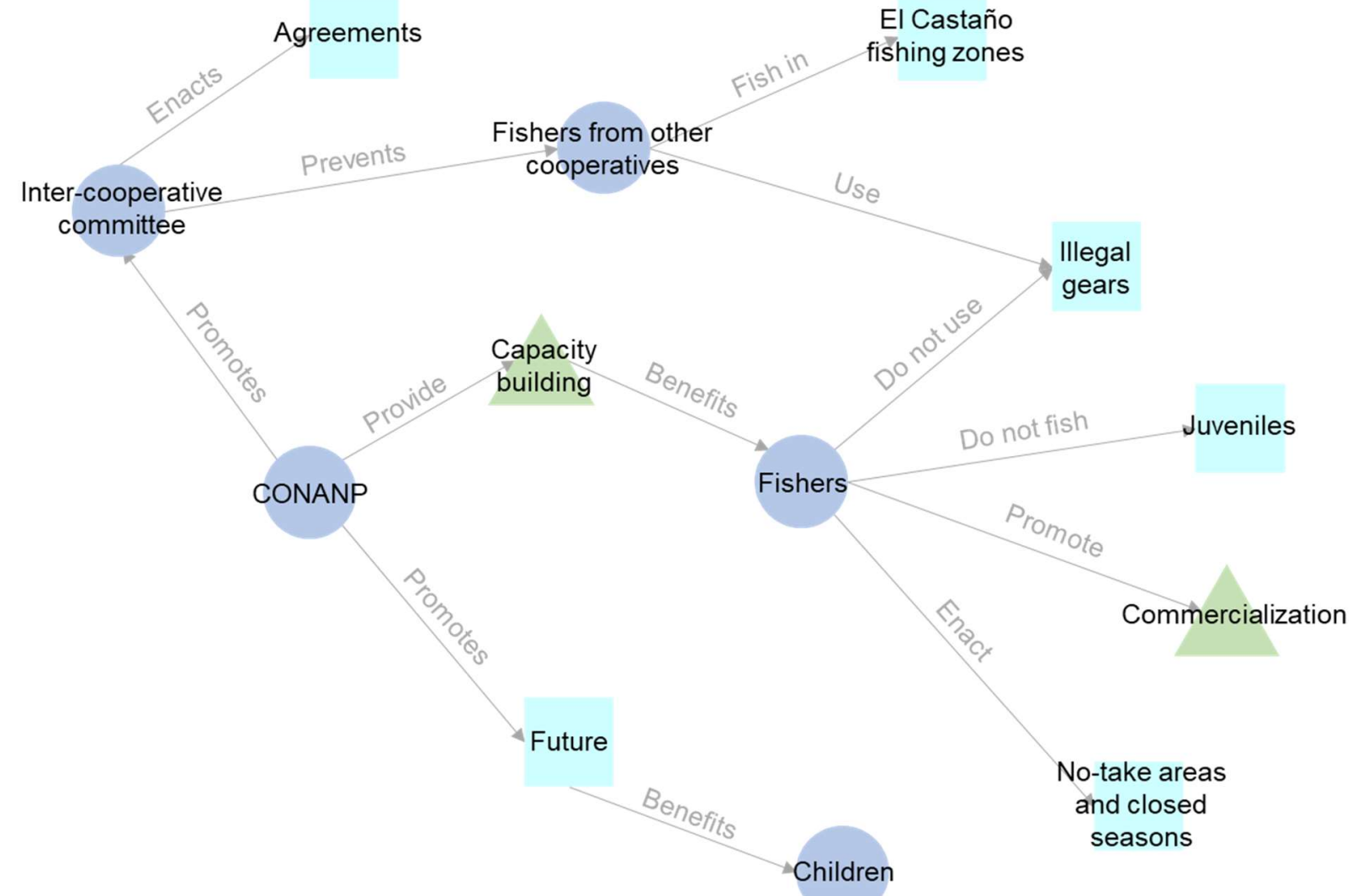

f) $\mathrm{LuCa06}$

Capacity Benefits
building 
g) $\mathrm{LuCa07}$

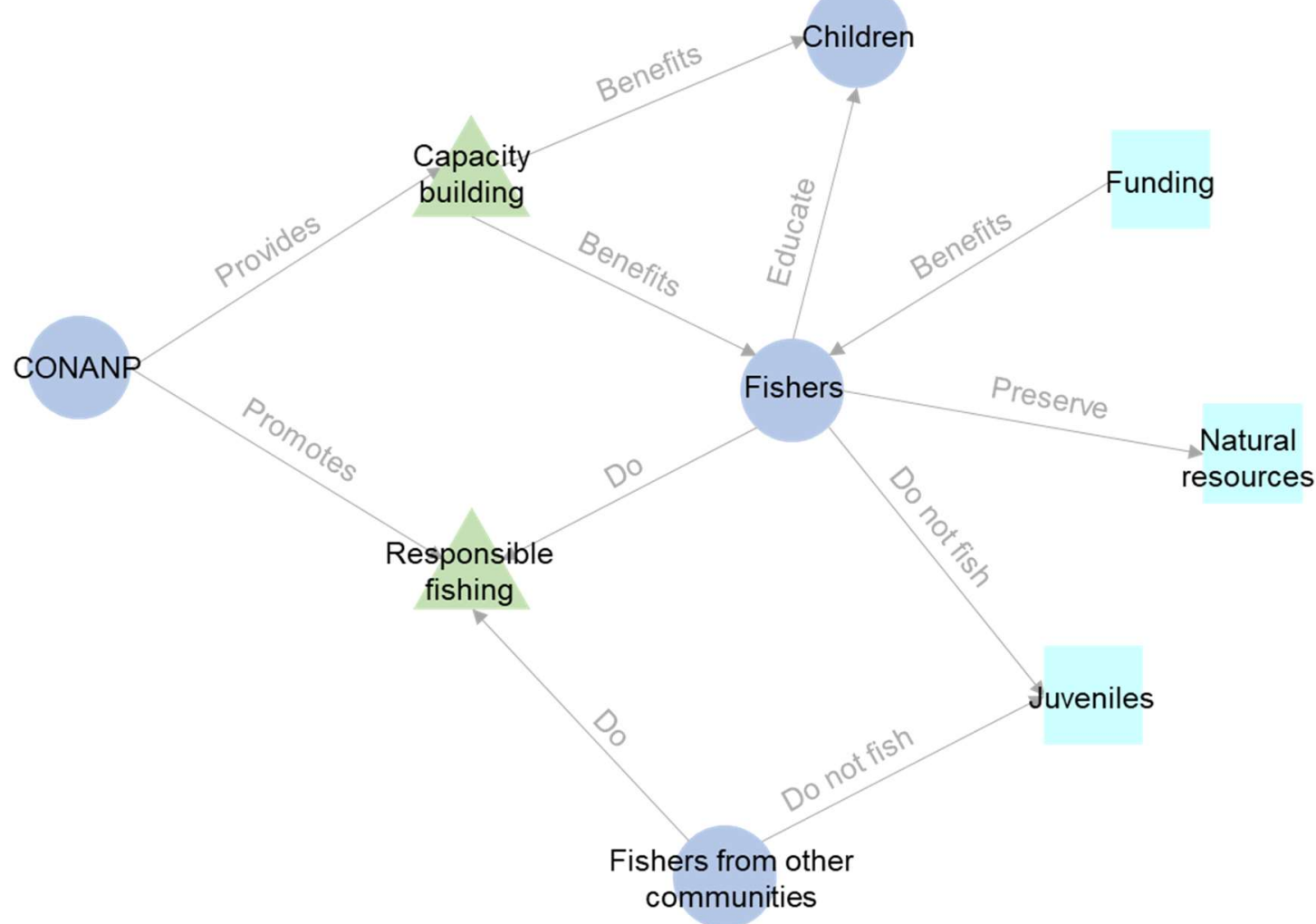

h) $\mathrm{LuCa08}$

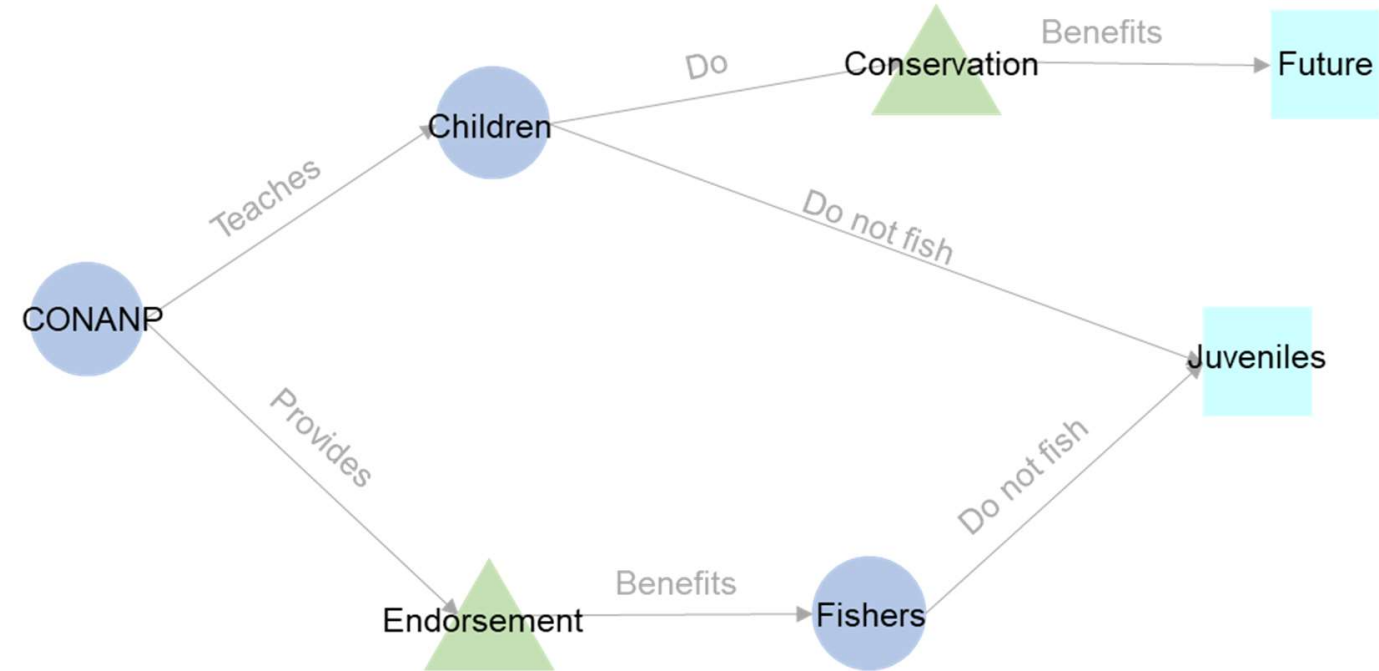


i) $\mathrm{LuCa09}$

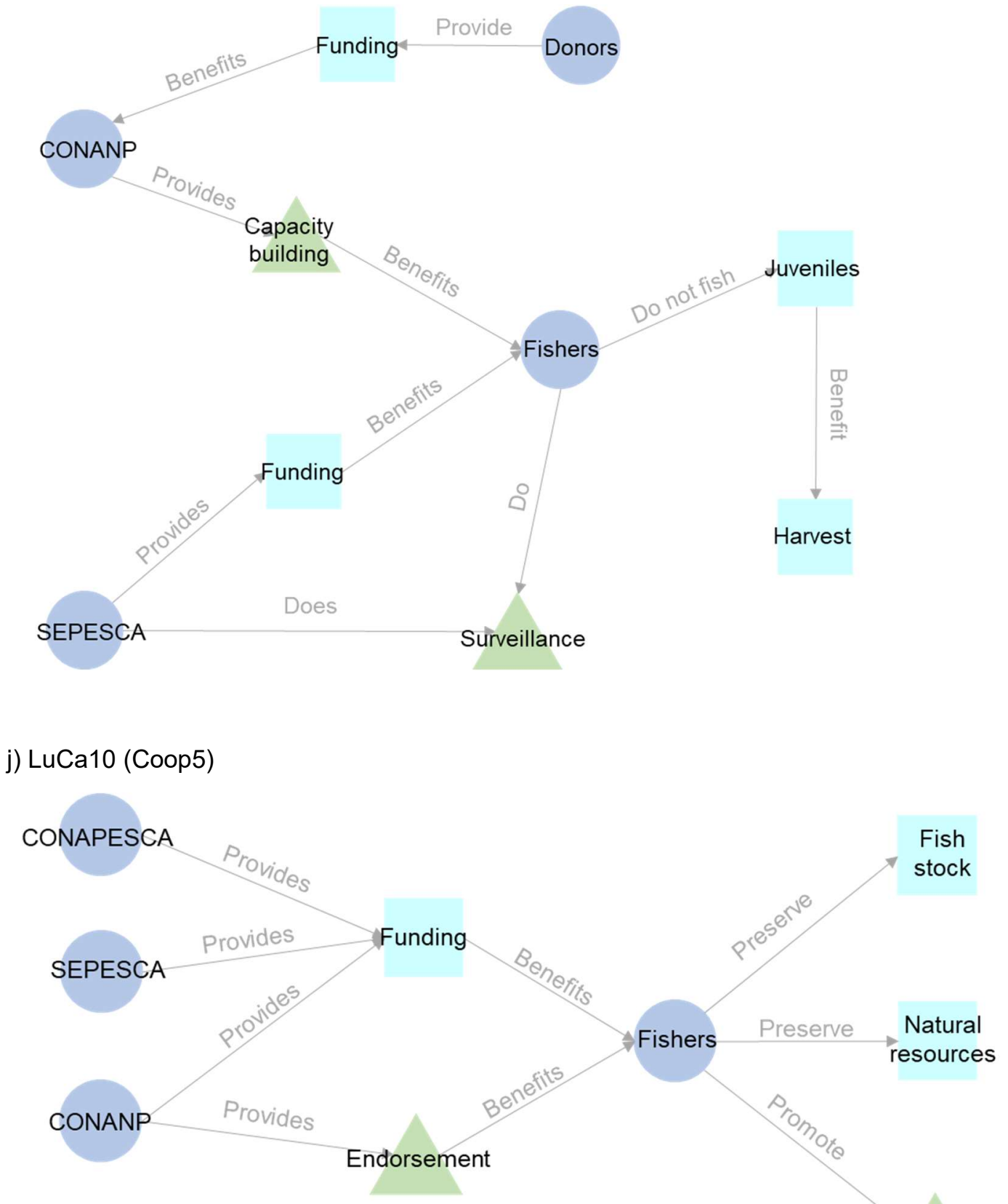

Commercialization 
k) LuCa11

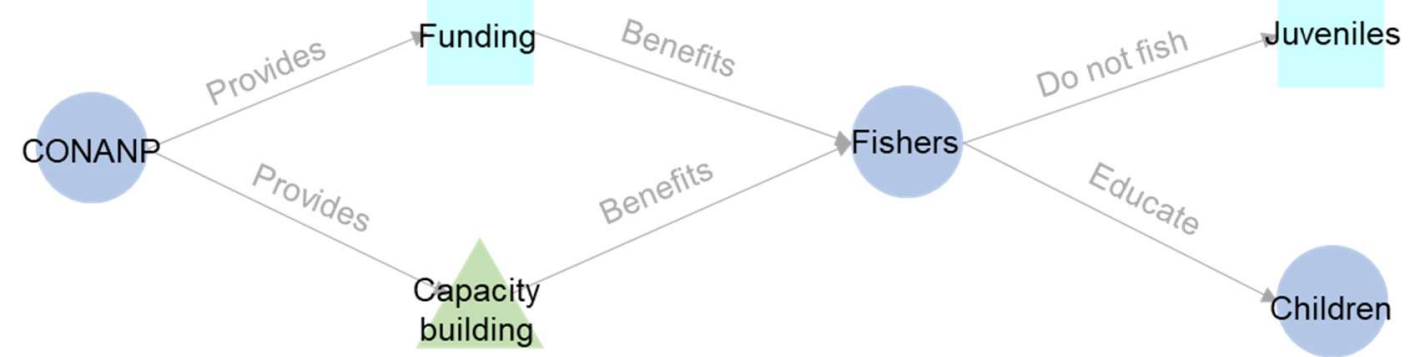

Legend

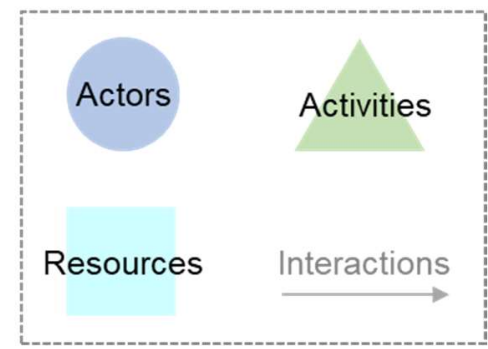

Fig. A3.3. Individual mental models of eleven members of Luchadores del Castaño fishing cooperative 
a) Gov1

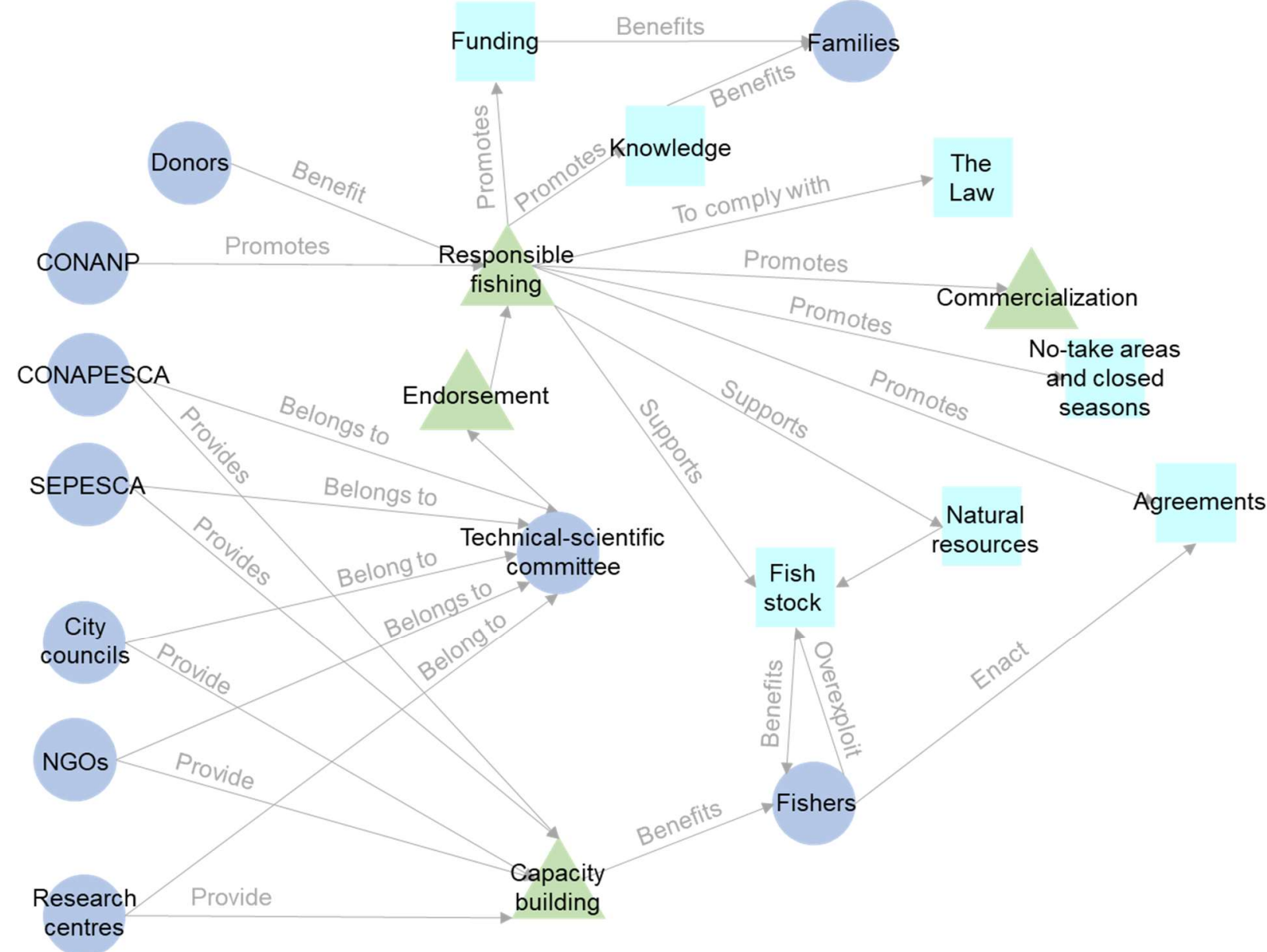


b) Gov2

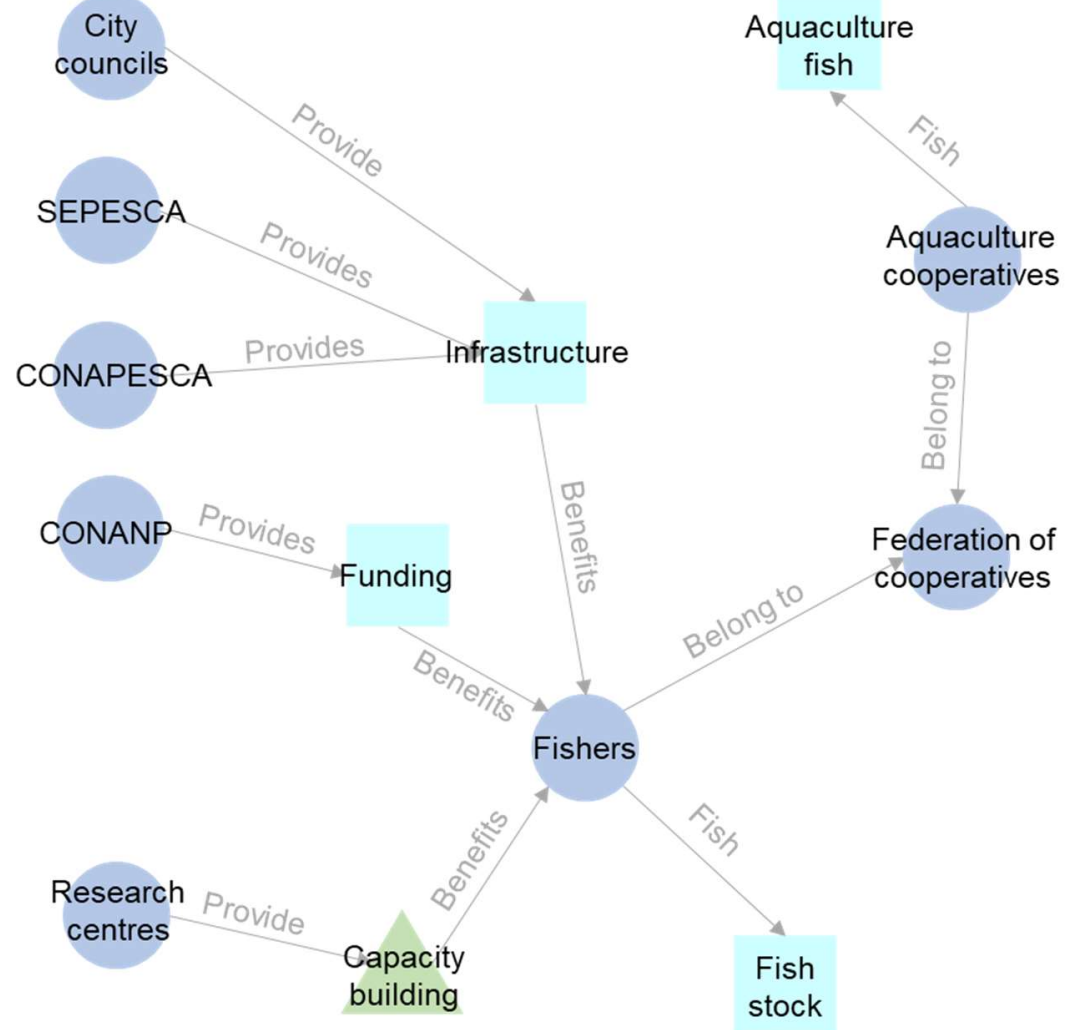


c) Gov3

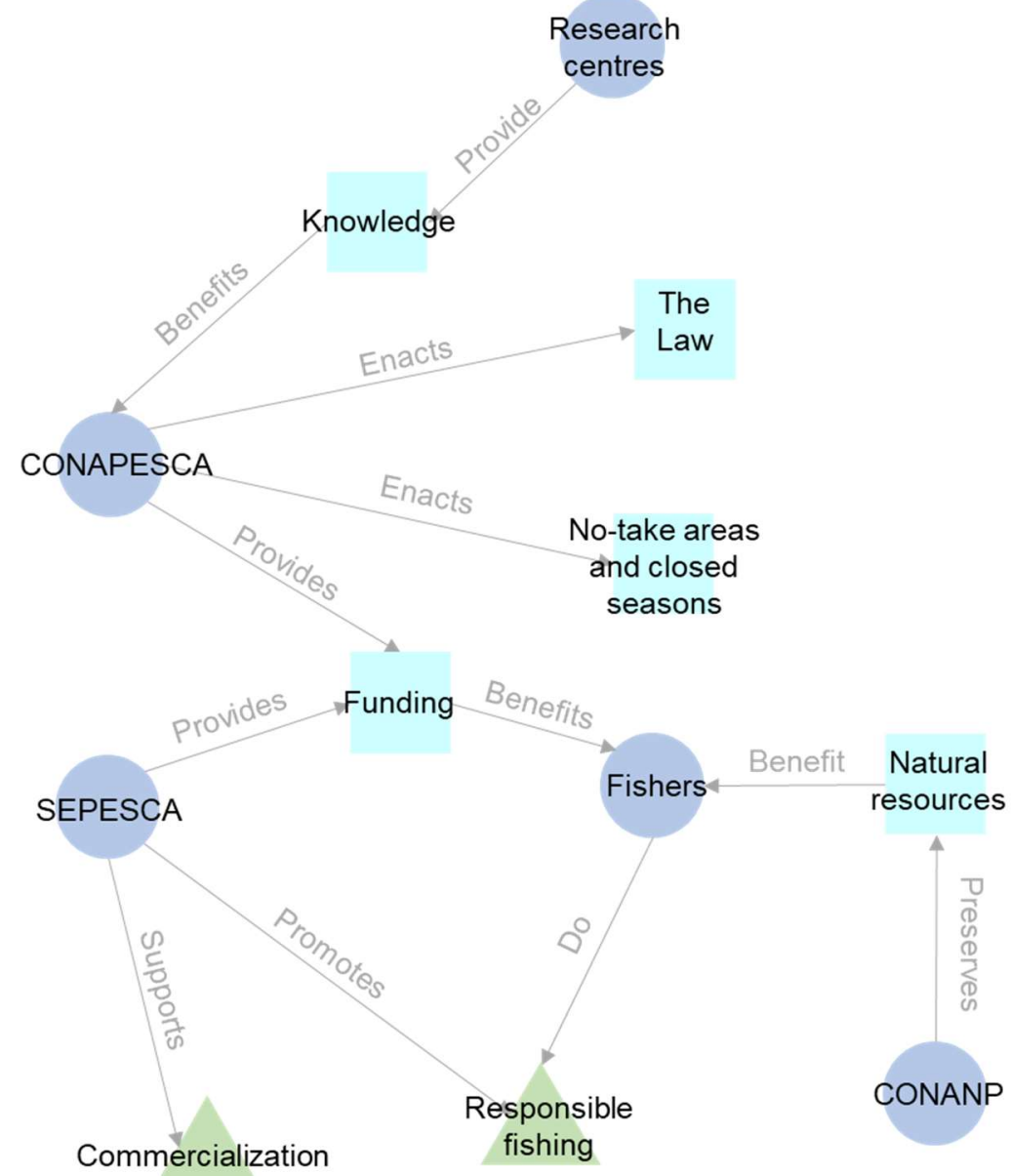


d) Gov4

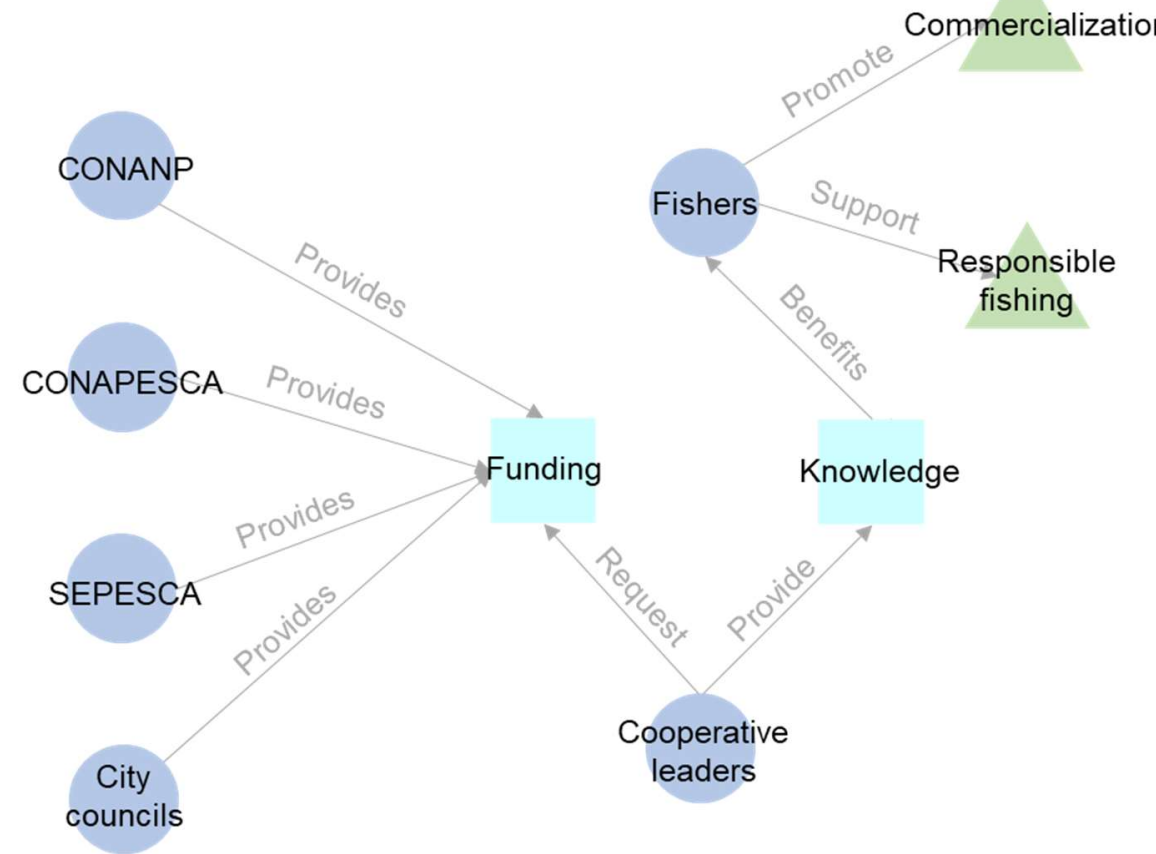

Fig. A3.4. Individual mental models of four government agencies' representatives

a) NGO1

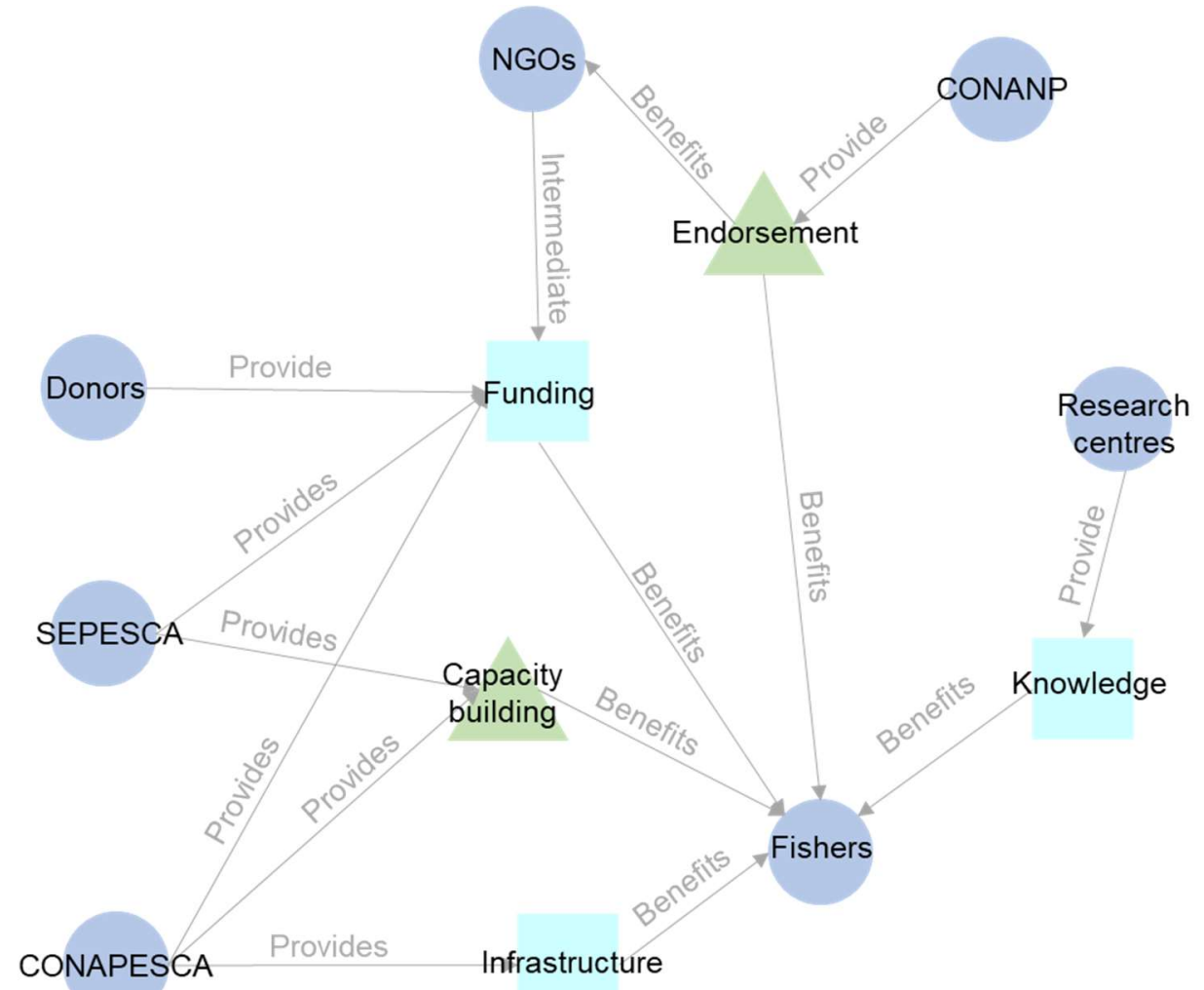


b) $\mathrm{NGO} 2$

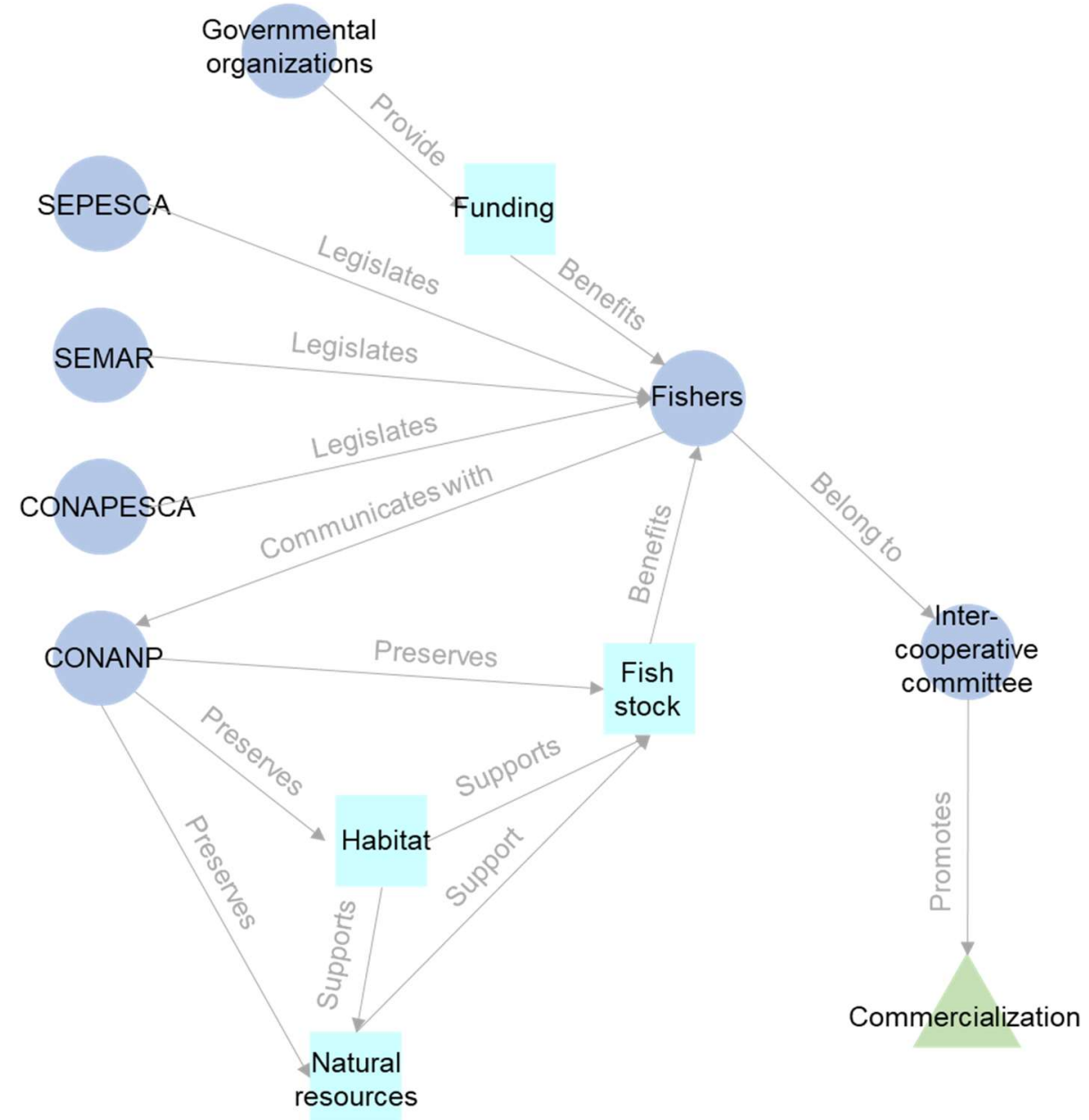


c) NGO3

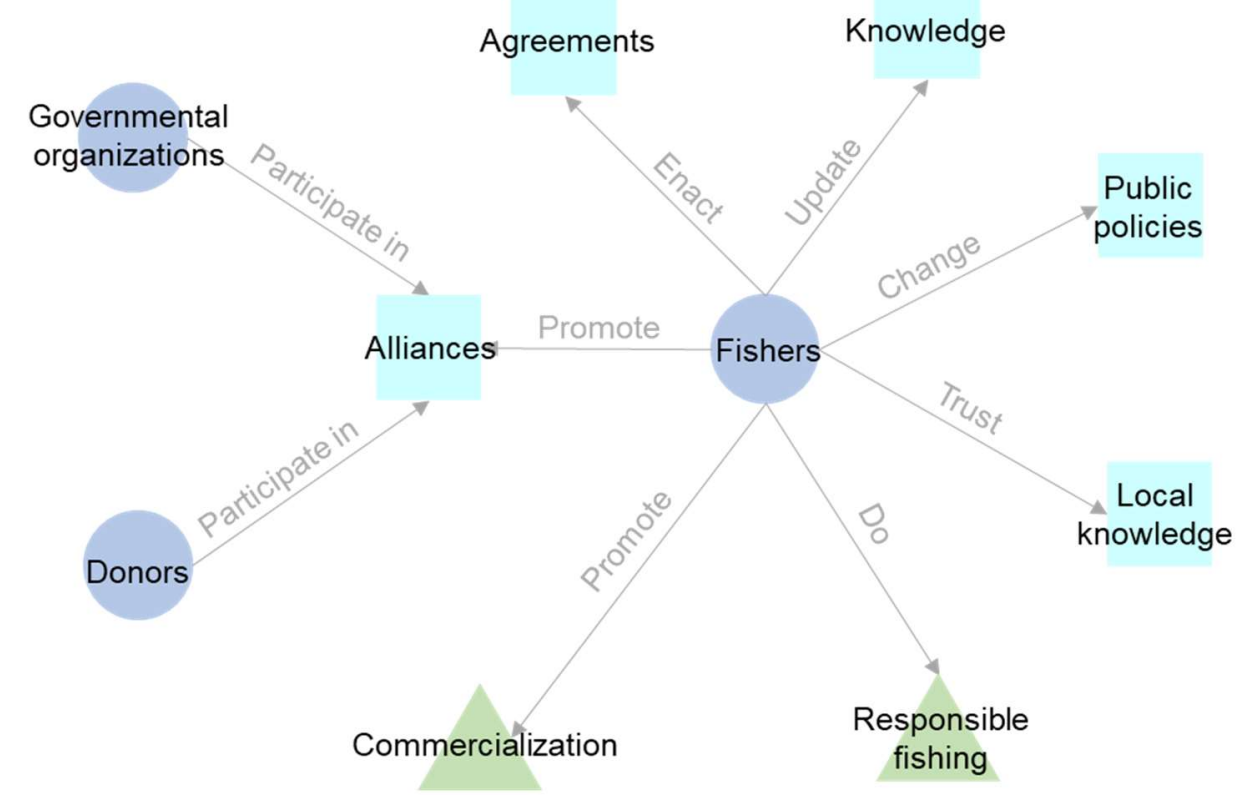

Legend

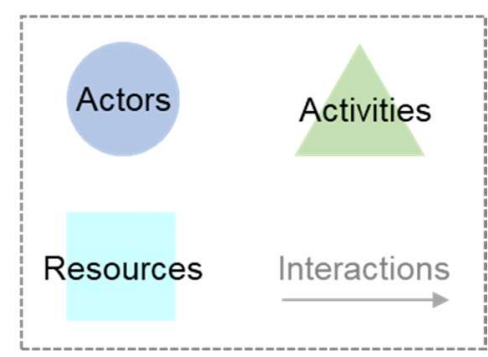

Fig. A3.5. Individual mental models of three NGOs' representatives 
Res1

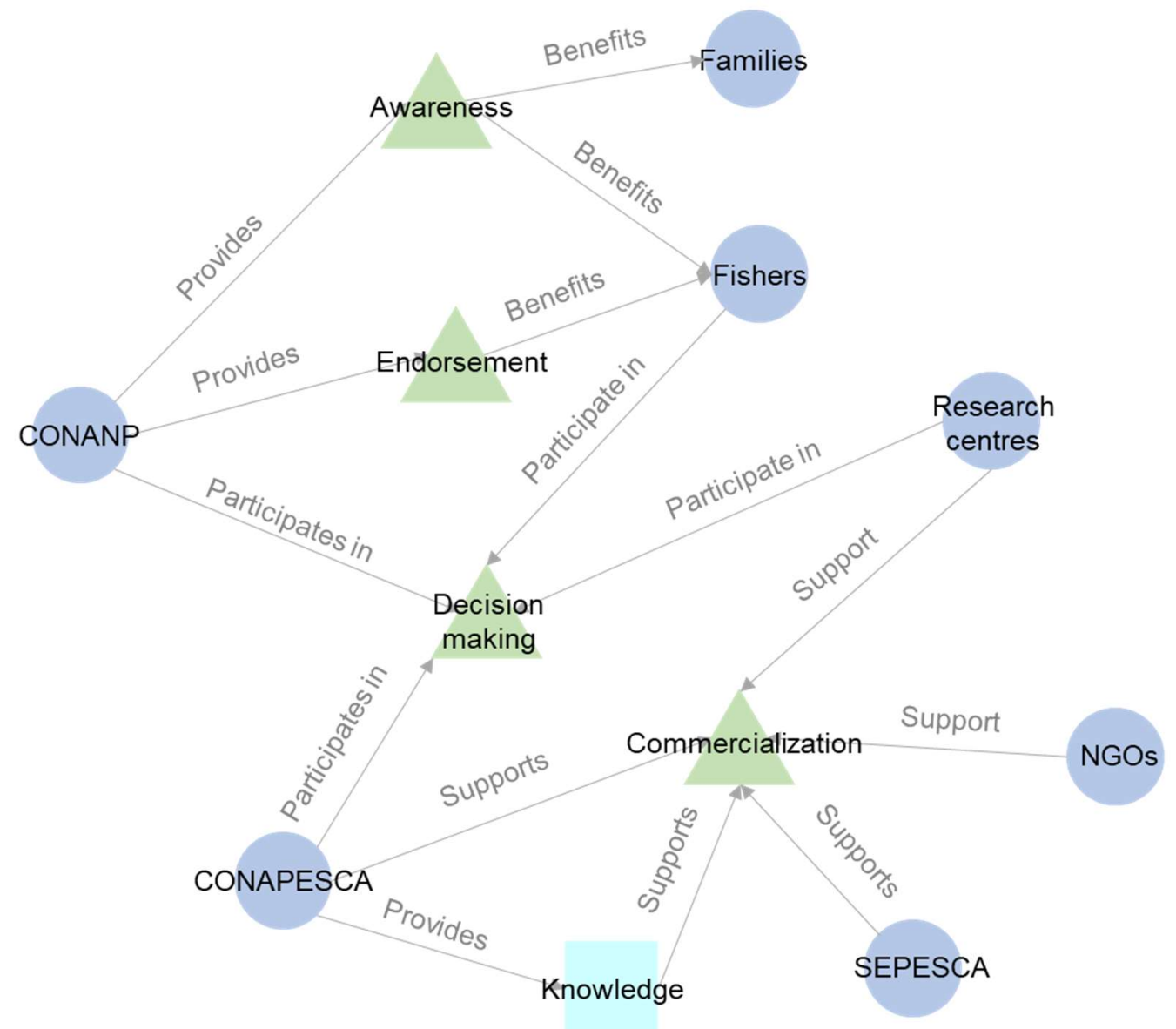

Legend

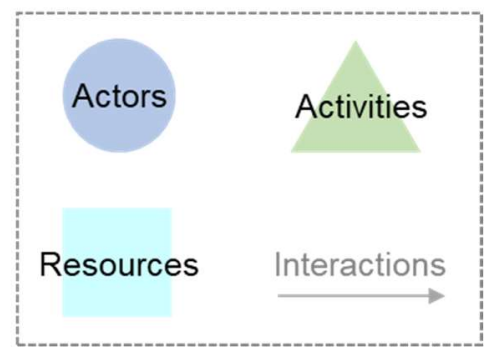

Fig. A3.6. Individual mental model of a research centre's representative 